\title{
Orogenic degassing, scapolitization and K-metasomatism during Caledonian exhumation, Helgeland, Norway
}

\author{
Kristian Drivenes ${ }^{1}$, Bjørn Eske Sørensen' \& Rune Berg Larsen ${ }^{1}$ \\ ${ }^{1}$ Department of Geology and Mineral Resources Engineering, Norwegian University of Science and Technology (NTNU), Sem Soelands veg 1, 7491 \\ Trondheim.
}

E-mail corresponding author (Kristian Drivenes): kristian.drivenes@ntnu.no

Metasomatism associated with barren quartz veins cross-cutting hornblende schist in the upper part of the metasedimentary sequence of the WMo-mineralized Bjellatinden area was studied using P-T modeling of the mafic schist host and alteration assemblages, fluid inclusions, and isocon diagrams. Two main alteration assemblages are associated with the quartz veins: A biotite-scapolite-dominated zone (BSZ), and a zone dominated by chlorite, muscovite and calcite (CMZ), replacing the former BSZ and extending further into the wall rock. Three types of fluid inclusions are observed: $\mathrm{CO}_{2}$-rich (type I), low-salinity $\mathrm{H}_{2} \mathrm{O}$-rich (type II), and high-salinity $\mathrm{H}_{2} \mathrm{O}$-rich (type III). Type III fluids are strongly associated with the CMZ, and are not observed in the BSZ, whereas type I and II fluids are observed in quartz and scapolite in the BSZ. Type I and II fluid inclusions found in quartz in the CMZ are interpreted to be relics from the earlier BSZ alteration. Plagioclase-amphibole thermobarometry of grains in the hornblende schist indicates a near-isothermal pressure drop from ca. 660 to ca. $560 \mathrm{MPa}$ at ca. $690^{\circ} \mathrm{C}$. Type I and II fluids are interpreted to have infiltrated extension fractures at ca. $240 \mathrm{MPa}$ and $600^{\circ} \mathrm{C}$ giving rise to the $\mathrm{BSZ}$, and only minor mass exchange with the hornblende schist. Type III fluids are responsible for K-metasomatism of the existing alteration assemblage, and infiltrated the pre-existing fracture system over a large temperature range, from ca. $600^{\circ} \mathrm{C}$ to ca. $350^{\circ} \mathrm{C}$ during near-isobaric cooling at ca. $200 \mathrm{MPa}$. The $\mathrm{CMZ}$ was stabilized towards the end of this fluid infiltration. The high-salinity fluids are interpreted to have exsolved from an underlying, unexposed, granitic intrusion. This intrusion may also be the source of the W-Mo mineralizations in the area.

Keywords: Metasomatism, W-Mo mineralization, scapolite, fluid inclusions, Caledonides

Electronic Supplement 1: Mineral chemical analyses.

Received 24. May 2015 / Accepted 11. May 2016 / Published online 21. July 2016

\section{Introduction}

The release of volatiles during orogenic exhumation has been well studied (e.g., Larsen et al., 1998; Smith \& Yardley, 1999; Vry et al., 2010). While large volumes of metamorphic fluids may be produced, their potential to metasomatically alter rocks is generally much lower than fluids generated from intrusions or sedimentary formation waters (Yardley, 2013). In this study we focus on hydrothermal alteration by fluids produced during the late stages of the Caledonian (Scandian) orogeny in the Bjellatinden area, located in the Meløy and Gildeskål municipalities, Nordland County, northern Norway. A number of $\mathrm{W}$ and Mo skarn and vein mineralizations are recorded in the area, two of which were mined periodically for molybdenite between 1917 and 1944. Scheelite was first discovered in 1953 in samples from the abandoned Oterstrand mine. Later, several Mo, $\mathrm{W}$ and $\mathrm{U}$ anomalies were found in the contact zone between the Caledonian nappe complexes and Precambrian basement rocks, and in stream sediments in the larger BodøGlomfjord region (Stendahl et al., 1993). Stratabound $\mathrm{W}$ mineralizations in Nordland have been explained as volcanic exhalative (Skaarup, 1974), magmatic (BowitzIhlen, 1973), and most recently, metamorphic (Larsen, 
1991). The apparent lack of intrusive bodies related to the Bjellatinden mineralizations, its semi-conformable character, and abundance of scapolite in the richest mineralized skarn body, make it comparable to examples from Massif Central, France (Gibert et al., 1992), Brazil (Barbosa et al., 1986), and the Archean Malene supracrustals (Appel, 1986). This area has had a complex fluid history, with at least two generations and sources of fluids infiltrating the metasedimentary stratigraphy. Most prominent, and not previously observed, are the brine fluids responsible for the K-metasomatism of the hornblende-mica schist during extensional collapse of the Caledonian orogeny in the Early Devonian.

A major enigma in explaining the $\mathrm{W}$ mineralization has been the dominance of nearly pure $\mathrm{CO}_{2}$ fluid inclusions related to the scheelite-bearing lithologies (Larsen, 1991). Given that W ions preferably are transported as various tungstates (Wood \& Samson, 2000), an aqueous component is required. In this study we report results from a poorly studied part of the area where several generations of volatiles were discovered. The fluids occur in structures and textural settings that relate to various episodes of exhumation of the orogenic roots, from possibly peak $\mathrm{T}$ metamorphism to the more advanced stages of orogenic collapse. Accordingly, when appended to the previous results, the Bjellatinden area exposes a well-preserved record of fluid evolution during the late-Scandian extensional collapse of the Caledonian orogeny.

\section{Geological setting}

\section{Regional geology}

The Scandinavian Caledonides are commonly divided into four tectonostratigraphic units: Lower, Middle, Upper, and Uppermost Allochthons (Roberts \& Gee, 1985), emplaced onto autochthonous Precambrian crystalline basement (Fig. 1A). Slices of crystalline basement and overlying shelf and continental-rise successions of Baltican origin, constitute the Lower and Middle Allochthons (Roberts \& Gee, 1985; Andréasson, 1994). More recently, the Seve Nappe, interpreted to represent the Baltica-Iapetus continent-ocean transition (Stephens \& Gee, 1985), has also been included in the Middle Allochthon (Gee et al., 2008). The Upper Allochthon comprises sedimentary and igneous rocks derived from the Iapetus Ocean, including ophiolites and island-arc complexes (e.g., Stephens, 1988; Grenne et al., 1999; Roberts, 2003) with faunas of Laurentian affinity (e.g., Bergström, 1979; Spjeldnæs, 1985; Bruton \& Harper, 1988). The Uppermost Allochthon was formed in a continental margin setting of Laurentian origin (e.g., Melezhik et al., 2002; Roberts et al., 2002, 2007), consisting of various metasedimentary, carbonate and magmatic units, and is divided geographically by the Paleoproterozoic Tysfjord basement window (Skår,
2002). North of the Tysfjord window, a number of unnamed and named thrust sheets, divided into Niingen, Tromsø, Gratangen, Nakkedal, Evenes, Lyngsfjell and Bjerkvik nappe complexes, are included in the Uppermost Allochthon (Barker, 1986; Zwaan et al., 1998; Melezhik et al., 2003). The Gratangen Nappe (including the Bogen Group) has been correlated with the Tromsø Nappe farther north, and the ophiolitic Bjerkvik Nappe has been correlated with the Lyngen Magmatic Complex of the Lyngsfjell Nappe (Andresen \& Steltenpohl, 1994), making the tectonostratigraphy (top to bottom) Niingen, Tromsø, Nakkedal, Evenes, and Lyngsfjell. South of the Tysfjord window, in tectonostratigraphic order top to bottom, Helgeland Nappe Complex (HNC), Beiarn Nappe Complex (BNC), and Rödingsfjället Nappe Complex (RNC) constitute the Uppermost Allochthon, with the $\mathrm{HNC}$ and $\mathrm{RNC}$ being the dominating units in terms of areal extent. The Fauske Nappe is in some maps shown as a separate unit (Roberts et al., 2007), but is generally interpreted to form the base of the RNC (Gustavson, 1996; Roberts et al., 2002). Correlations of the BNC to either the HNC (Stephens et al., 1985) or the RNC (Gustavson \& Gjelle, 1991; Gustavson, 1996) have been proposed, but it may very well be seen as a separate complex (Augland et al., 2012). Zircon ages in the HNC resemble those in sedimentary zircons from the Dalradian Supergroup of Scotland (Barnes et al., 2007), while $\varepsilon_{\mathrm{Hf}(\mathrm{t})}$-values in zircons from magmatic intrusions in the Beiarn Nappe correspond to those in the Hurry Inlet plutonic terrane in Liverpool Land, NE Greenland (Augland et al., 2012). Furthermore, Taconian structures in the HNC (Yoshinobu et al., 2002; Barnes et al., 2007) and the RNC (Roberts et al., 2002) underline the exotic origin of the Uppermost Allochthon.

Dating of migmatites and plutonic intrusions have indicated that the continental collision during peak Scandian orogenesis lasted ca. 25 million years from 425 Ma to 401 $\mathrm{Ma}$, including a period of uplift of basement windows and related decompression melting responsible for the emplacement of pegmatite bodies from $409 \pm 5 \mathrm{Ma}$ to $401 \pm 2 \mathrm{Ma}$ (Larsen et al., 2002; Nordgulen et al., 2002), followed by extensional collapse and unroofing between $401 \mathrm{Ma}$ and $398 \mathrm{Ma}$ (Braathen et al., 2002; Eide et al., 2002; Osmundsen et al., 2003).

\section{Geology of the Biellatinden area}

The quartz monzonitic 'Bjellatind granite' comprises, together with the larger Glomfjord, Svartisen, Høgtuva, and Sjona windows, a group of Proterozoic, autochthonous basement windows yielding zircon $\mathrm{U}-\mathrm{Pb}$ ages of $1800 \pm 3$ to $1795 \pm 5 \mathrm{Ma}$ (Skår, 2002). Coinciding with late-Svecofennian magmatism and the earliest intrusions of the Transscandinavian Igneous Belt (Skår \& Pedersen, 2003), they are interpreted to be a part of the western margin of the Fennoscandian Shield. 

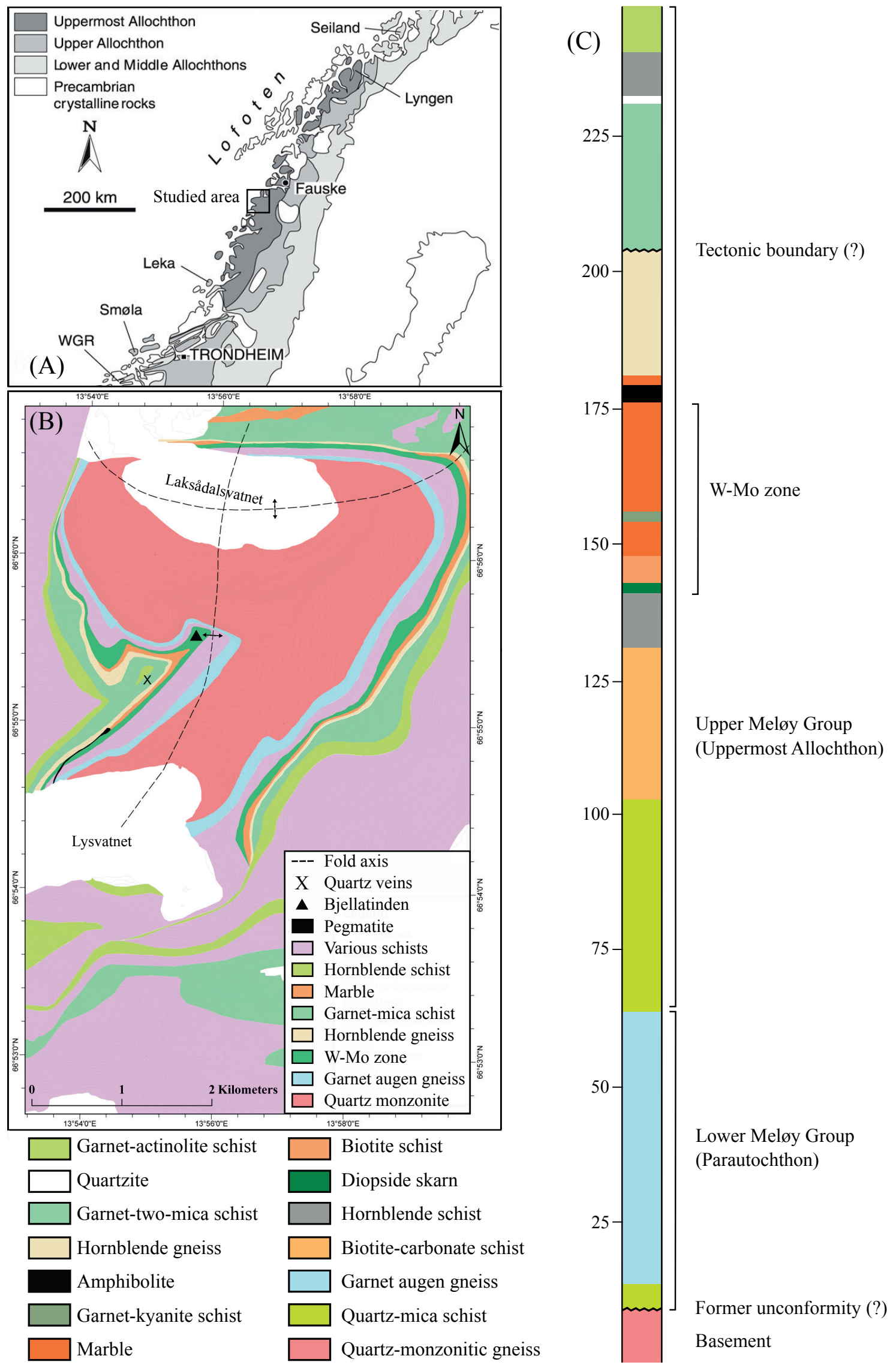

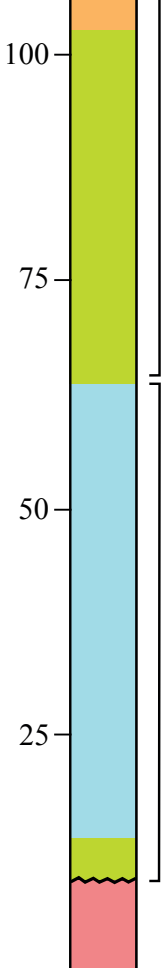

Lower Meløy Group (Parautochthon)

(Uppermost Allochthon)

Former unconformity (?)

Basement

Figure 1. (A) Overview of the principal allochthonous units in northern Norway (Roberts et al., 2007). The studied area is indicated by the small rectangle. (B) Local map of the Bjellatinden area based on Wells \& Bradshaw (1970), Larsen (1988) and this study. (C) Lithological column through the metasedimentary units. The column is representative of the area near the quartz veins ' $X$ '. Based on Larsen (1988) and this study. 
Overlying the Bjellatind granite is a metasedimentary suite of gneisses, schists, amphibolites, and marbles (Fig. 1B, C) known as the Meløy Group, or Meløy Nappe (Hollingworth et al., 1960). The lowermost lithologies of the Meløy Group ("Lower Meløy Group" of Hollingworth et al. (1960), and "basal succession" of Holmes, 1966) consisting of garnet augen gneiss and thin layers of psammite and mica schist towards the top, are thought to be (par)autochthonous. The presumed original unconformity between the basement and the directly overlying strata was destroyed by intense $\mathrm{F}_{1}$ folding (Rutland \& Nicholson, 1965). The Gildeskål marbles have been correlated with the Fauske marbles around Saltfjord, a part of the Fauske Nappe (Rutland \& Nicholson, 1965), and the Upper Meløy Group of Hollingworth et al. (1960) (corresponding to the Galtskartind succession of Holmes, 1966) is thus a part of the RNC of the Uppermost Allochthon.

The boundary between the hornblende gneiss and the overlying kyanite-bearing garnet- two- mica schist is in places marked by an intensely deformed marble layer of varying thickness (Larsen, 1988). Cribb (1981) also noted a difference in age between these two lithologies (1199 $\pm 161 \mathrm{Ma}$ for the kyanite schist, and a maximum age of 758 Ma for the precursor of the hornblende gneiss) based on whole-rock $\mathrm{Rb}-\mathrm{Sr}$ geochronology. This dating technique is today regarded as imprecise, and the $758 \mathrm{Ma}$ age may well represent a resetting of the whole-rock $\mathrm{Rb}-\mathrm{Sr}$ system. However, intensive shearing of the marble unit associated with thinning and even disappearance implies a tectonic boundary (Larsen, 1991). The metasedimentary rocks occurring some tens of meters below the hornblende gneiss and the marble, where present, are characterized by intense deformation and W-Mo mineralized fractures, and are dubbed the $\mathrm{W}-\mathrm{Mo}$ zone. All W-Mo mineralizations are situated in this 15-40 m-thick composite layer, comprising calcareous biotite schist, marbles, and calcsilicate rocks. Within this layer, scheelite and molybdenite occur in a scapolite replacement skarn, in addition to quartz, quartz-plagioclase, and quartz-calcite veins (Larsen, 1991). Scheelite also occurs in a 0.3-8 m-thick diopside replacement skarn, but here Mo is absent (Drivenes, 2010). A $20 \mathrm{~cm}$-thick layer of diopside skarn is situated above a garnet-bearing schist in the upper lithologies, but no scheelite was observed in this layer. Typical grades vary from a few hundred $\mu \mathrm{g} / \mathrm{g}$ to 1.5 mass $\% \mathrm{~W}$, and up to 0.2 mass $\%$ Mo. $\mathrm{CO}_{2-}$ dominated fluids imply formation at 450 to $525^{\circ} \mathrm{C}$ and $200 \mathrm{MPa}$ (Larsen, 1991).

A ca. eight meter-thick layer of hornblende schist, situated above the garnet- two-mica schist, is in the lower three meters intersected by a stockwork of 5-15 cm-wide quartz veins with alteration halos up to $5 \mathrm{~cm}$ in width. The veins also cross-cut earlier quartz veins parallel to the foliation (Fig. 2). These veins and their alterations

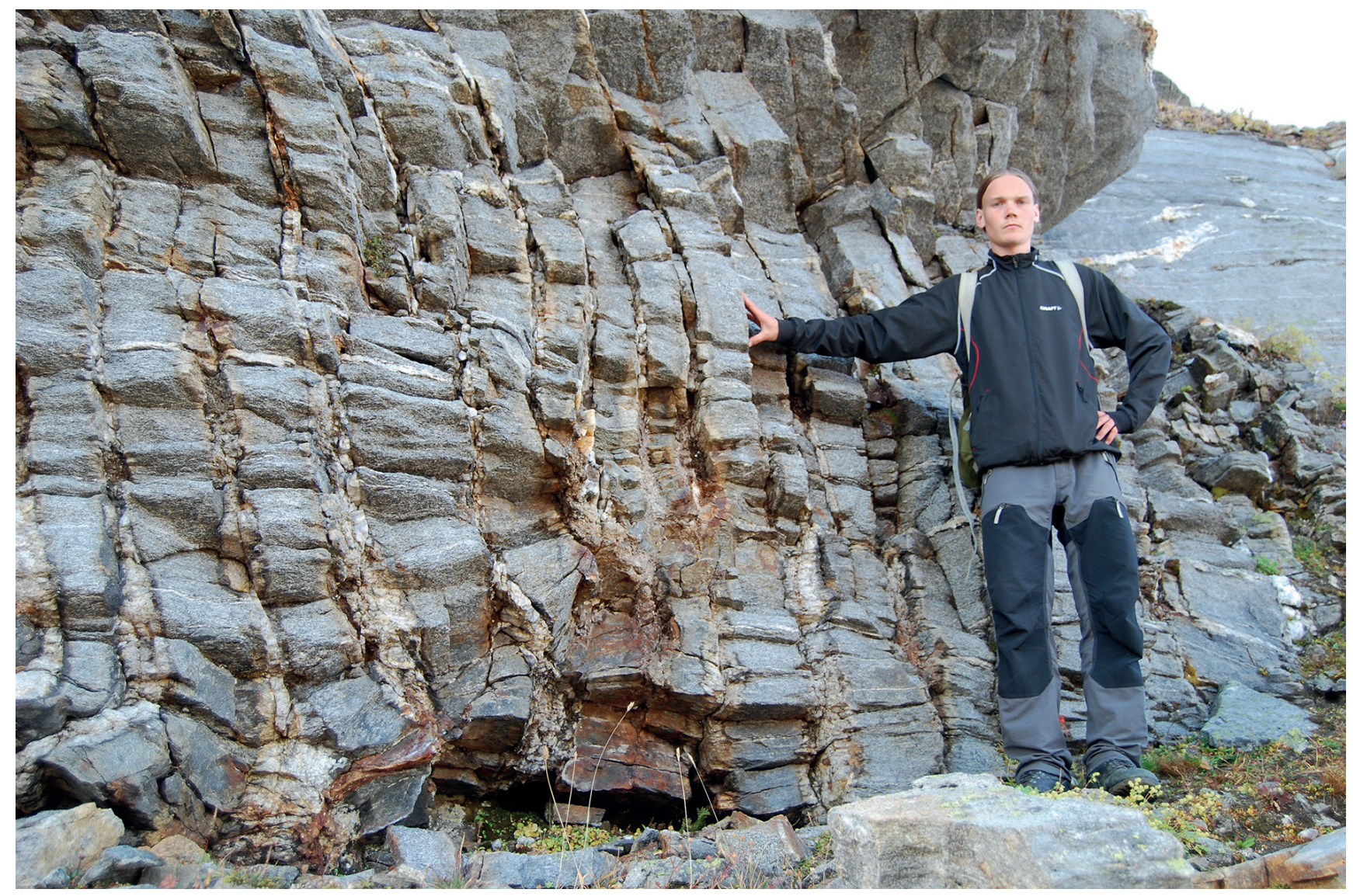

Figure 2. Field appearance of cross-cutting quartz veins in location ' $X$ ' in Fig. $1 B$. 
are the focus of this study. The veins gradually taper upwards into unfilled joint-like fractures continuing 1-2 meters on the very top. The vein swarm can be followed for 250 meters along the dip direction of the hornblende schist. Similar veins with the same orientation are located 200 meters along strike, but lacking the alteration halos. In these veins, dense clusters of coarse biotite grains $(\sim 5 \mathrm{~cm})$ occur in the center of the veins. The boundary between the garnet- two-mica schist and the hornblende schist is marked by a one meter-thick quartzite layer. A one meter-thick marble layer, situated above the hornblende schist, is overlain by at least 100 meters of various amphibole-, garnet-, and carbonate-bearing schists and psammites.

A tourmaline-rich, S-type granitic pegmatite body, similar to other pegmatites that formed from decompression melting during gneiss dome uplift (Barnes et al., 2007), intruded at the stratigraphic level of the hornblende gneiss and the $\mathrm{W}-$ Mo zone. It consists of subconformable sheets 5-20 m thick, with subvertical dike offshoots intersecting the overlying lithologies.

\section{Structural setting}

Three major folding episodes dominate the area. The early $F_{1}$ episode is represented by isoclinal folds in the basement gneisses with an axial plane schistosity parallel to the cover rock contacts (Rutland \& Nicholson, 1965), which formed during nappe emplacement (Wells \& Bradshaw, 1970). These features were in turn refolded during a later $\mathrm{F}_{2}$ episode producing tight, overturned folds, such as those observed in the marble layers between the hornblende gneiss and the garnet- two-mica schist, as well as larger fold structures such as the Spilderdalen antiform (Holmes, 1966). The most obvious structural element of the Bjellatinden area is the asymmetrical dome shape caused by $\mathrm{F}_{3}$ folding during exhumations in the late stages of the orogeny. Large, open, antiformal domes were created by interfering folds with $\mathrm{N}-\mathrm{S}$ and $\mathrm{E}-\mathrm{W}$ fold axes (Fig. 1B). Layers on the Bjellatinden plateau are subhorizontal, dipping ca. $10^{\circ} \mathrm{W}$-SW, with increasing dips toward the flanks of the dome. On the northern slope of the dome, the layering is near-vertical to slightly overturned. Boudinage structures on the flanks of the dome, as exemplified by chocolate tablet boudins of hornblende gneiss in marble in one of the $\mathrm{W}$-mineralized zones, and other boudinage phenomena on a smaller scale, were caused by extension and thinning during the $\mathrm{F}_{3}$ doming event. Brittle fracturing of competent lithologies, such as the hornblende gneiss, is also ascribed to extensional thinning (Osmundsen et al., 2003).

\section{Analytical methods}

Alteration zones were identified based on mineralogy from macroscopic observations. The different zones were then cut out and analyzed microscopically. Bulk chemical analyses of major elements (Table 1) were done by wavelength dispersive XRF on a Bruker S8 Tiger, and trace elements (Table 2) by a combination of XRF and aqua regia ICP-MS, using an Elan DRC-II. Nickel, Cu, Zn, $\mathrm{Rb}, \mathrm{Sr}$ and $\mathrm{Zr}$ were analyzed by XRF using the standardized Geoquant software package. The remaining trace elements in Table 2 were analyzed by ICP-MS. Electron microprobe spot analyses were performed using a JEOL JXA-8500F hyper probe with beam current and acceleration voltage set to $30 \mathrm{nA}$ and $15 \mathrm{kV}$, respectively. During construction of element maps of decrepitated fluid inclusions, voltage was set to $10 \mathrm{kV}$. For the plagioclase-hornblende geothermometry, only spots with totals above $98.0 \%$ for plagioclase, and 96.0 mass\% for amphibole were selected. All microprobe runs were calibrated using mineral standards from Astimex Scientific ltd.

Microthermometry was performed using a Linkam THMSG 600 heating/freezing stage controlled by Linkam 32 software, and calibrated using synthetic fluid inclusions from Bubbles Inc. Isochores were calculated using the FLUIDS 1 package (Bakker, 2003) and equations of Bodnar \& Vityk (1994).

\section{Results}

\section{Mineralogy}

Two distinct types of alteration can be observed in the hornblende schist, adjacent to the quartz veins: One dominated by chlorite, muscovite, and calcite (the chlorite-muscovite zone, CMZ), most prominent in the lower parts, and a visually more subtle zone, dominated by biotite, scapolite, and calcite (biotite-scapolite zone, BSZ).

Table 1. Major element compositions (mass\%).

\begin{tabular}{|c|c|c|c|c|}
\hline Sample & Unaltered & Bt-scp zone & Chl zone & Ms-cc zone \\
\hline $\mathrm{Fe}_{2} \mathrm{O}_{3}$ & 6.21 & 5.53 & 8.94 & 4.47 \\
\hline $\mathrm{TiO}_{2}$ & 0.60 & 0.65 & 1.04 & 0.37 \\
\hline $\mathrm{CaO}$ & 6.18 & 2.60 & 3.65 & 5.31 \\
\hline $\mathrm{K}_{2} \mathrm{O}$ & 1.77 & 2.44 & 1.58 & 6.38 \\
\hline $\mathrm{P}_{2} \mathrm{O}_{5}$ & 0.09 & 0.06 & 0.19 & 0.11 \\
\hline $\mathrm{SiO}_{2}$ & 60.37 & 72.85 & 60.92 & 56.76 \\
\hline $\mathrm{Al}_{2} \mathrm{O}_{3}$ & 16.54 & 8.94 & 15.92 & 22.58 \\
\hline $\mathrm{MgO}$ & 3.24 & 3.24 & 3.32 & 1.78 \\
\hline $\mathrm{Na}_{2} \mathrm{O}$ & 2.89 & 0.65 & 2.38 & 0.00 \\
\hline $\mathrm{MnO}$ & 0.09 & 0.05 & 0.04 & 0.07 \\
\hline Sum & 97.98 & 97.00 & 98.98 & 97.82 \\
\hline LOI & 0.74 & 1.36 & 3.76 & 7.52 \\
\hline
\end{tabular}


Table 2. Trace element compositions ( $\mu \mathrm{g} / \mathrm{g})$.

\begin{tabular}{|c|c|c|c|c|}
\hline Sample & Unaltered & Bt-scp zone & Chl zone & Ms-cc zone \\
\hline$\overline{\mathrm{Li}}$ & 19.2 & 45.5 & 42.7 & 37.2 \\
\hline B & 4.2 & 1.6 & 2.0 & 13.7 \\
\hline Sc & 41.0 & 49.8 & 42.9 & 35.5 \\
\hline V & 122.7 & 128.4 & 163.6 & 96.3 \\
\hline $\mathrm{Cr}$ & 19.0 & 18.6 & 18.6 & 9.9 \\
\hline $\mathrm{Ni}$ & 93.1 & 76.1 & 119.6 & 61.5 \\
\hline Co & 15.7 & 8.4 & 12.9 & 4.2 \\
\hline $\mathrm{Cu}$ & 4.4 & 8.4 & 2.6 & 1.8 \\
\hline $\mathrm{Zn}$ & 64.7 & 78.0 & 75.2 & 53.3 \\
\hline $\mathrm{Ga}$ & 18.0 & 16.1 & 16.4 & 31.7 \\
\hline $\mathrm{Ge}$ & $<3$ & $<3$ & $<3$ & $<3$ \\
\hline As & 2.6 & $<0.5$ & 1.2 & 0.9 \\
\hline $\mathrm{Se}$ & $<30$ & $<30$ & $<30$ & $<30$ \\
\hline $\mathrm{Rb}$ & 16.1 & 31.0 & 20.2 & 46.4 \\
\hline $\mathrm{Sr}$ & 131.6 & 53.4 & 112.5 & 17.2 \\
\hline Y & 3.9 & 2.5 & 4.6 & 0.0 \\
\hline $\mathrm{Zr}$ & 20.3 & 17.6 & 26.5 & 13.3 \\
\hline $\mathrm{Nb}$ & 9.1 & 9.5 & 13.7 & 5.9 \\
\hline Mo & $<0.4$ & $<0.4$ & $<0.4$ & $<0.4$ \\
\hline $\mathrm{Ru}$ & $<3$ & $<3$ & $<3$ & $<3$ \\
\hline $\mathrm{Rh}$ & $<0.01$ & $<0.01$ & $<0.01$ & $<0.01$ \\
\hline $\mathrm{Ag}$ & 1.6 & $<0.8$ & $<0.8$ & 2.1 \\
\hline $\mathrm{Cd}$ & $<2$ & $<2$ & $<2$ & $<2$ \\
\hline Sn & 2.2 & 0.9 & 1.0 & 4.2 \\
\hline $\mathrm{Sb}$ & $<2$ & $<2$ & $<2$ & $<2$ \\
\hline $\mathrm{Te}$ & $<600$ & $<600$ & $<600$ & $<600$ \\
\hline Cs & 0.4 & 3.3 & 3.3 & 3.0 \\
\hline $\mathrm{Ba}$ & 184.9 & 219.4 & 118.4 & 379.0 \\
\hline $\mathrm{La}$ & 4.8 & 4.6 & 7.9 & 0.0 \\
\hline $\mathrm{Ce}$ & 33.9 & 22.7 & 35.9 & 9.1 \\
\hline $\operatorname{Pr}$ & 1.5 & 1.4 & 2.3 & 0.0 \\
\hline $\mathrm{Nd}$ & $<100$ & $<100$ & $<100$ & $<100$ \\
\hline Sm & $<3$ & $<3$ & $<3$ & $<3$ \\
\hline $\mathrm{Eu}$ & $<0.3$ & $<0.3$ & $<0.3$ & $<0.3$ \\
\hline Gd & $<4$ & $<4$ & $<4$ & $<4$ \\
\hline $\mathrm{Tb}$ & $<1$ & $<1$ & $<1$ & $<1$ \\
\hline Dy & $<1$ & $<1$ & $<1$ & $<1$ \\
\hline Ho & $<0.5$ & $<0.5$ & $<0.5$ & $<0.5$ \\
\hline $\mathrm{Er}$ & $<2$ & $<2$ & $<2$ & $<2$ \\
\hline $\mathrm{Tm}$ & $<1$ & $<1$ & $<1$ & $<1$ \\
\hline $\mathrm{Yb}$ & $<3$ & $<3$ & $<3$ & $<3$ \\
\hline $\mathrm{Lu}$ & $<1$ & $<1$ & $<1$ & $<1$ \\
\hline Hf & 1.0 & 0.8 & 1.1 & $<0.7$ \\
\hline $\mathrm{Ta}$ & 0.8 & 0.7 & 1.2 & 0.4 \\
\hline W & $<2$ & $<2$ & $<2$ & $<2$ \\
\hline Os & $<2$ & $<2$ & $<2$ & $<2$ \\
\hline Ir & $<0.1$ & $<0.1$ & $<0.1$ & $<0.1$ \\
\hline $\mathrm{Pt}$ & $<8$ & $<8$ & $<8$ & $<8$ \\
\hline $\mathrm{Au}$ & $<40$ & $<40$ & $<40$ & $<40$ \\
\hline $\mathrm{Tl}$ & 0.2 & 0.8 & 0.8 & 0.8 \\
\hline $\mathrm{Pb}$ & 168.4 & 121.9 & 0.0 & 0.0 \\
\hline $\mathrm{Bi}$ & $<0.7$ & $<0.7$ & $<0.7$ & $<0.7$ \\
\hline Th & 3.1 & 3.5 & 8.6 & $<0.6$ \\
\hline $\mathrm{U}$ & 2.2 & $<2$ & $<2$ & $<2$ \\
\hline
\end{tabular}

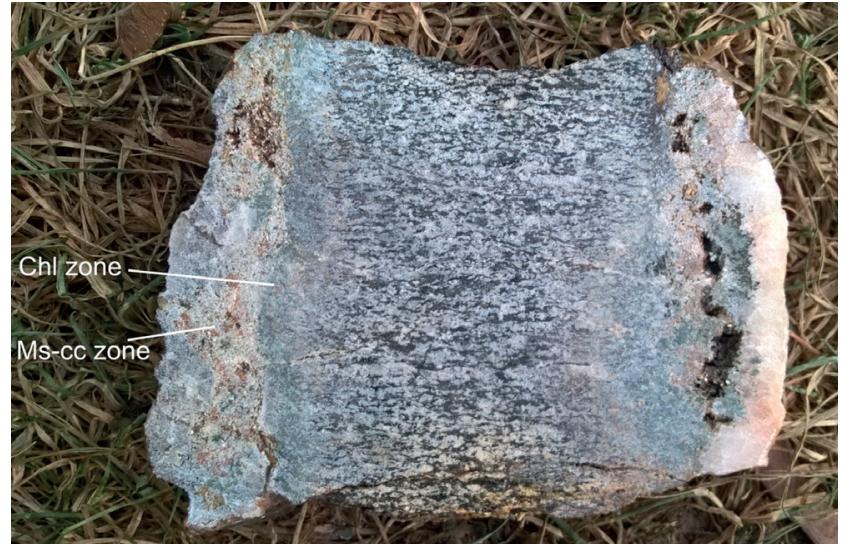

Figure 3. Example of the CMZ and the transition to unaltered hornblende schist between two quartz veins. The chlorite and muscovite-calcite subzones are indicated.

The extent of the alteration zones varies from a few $\mathrm{mm}$ to several $\mathrm{cm}$ (Fig. 3). Major and trace element compositions of the alteration zones are listed in Tables 1 and 2, respectively. All electron microprobe analyses are listed in Electronic Supplement 1.

\section{Hydrothermally unaltered hornblende schist}

The hydrothermally unaltered schist is composed mainly of plagioclase, green hornblende, brown biotite, and quartz, with minor K-feldspar and accessory titanite, clinozoisite, zircon, apatite, and calcite. Foliation is marked by $200 \mu \mathrm{m}$ to $2 \mathrm{~mm}$ elongated, subhedral nematoblastic hornblende, mostly of edenitic to pargasitic composition (Fig. 4A), and lepidoblastic biotite grains. Reversezoned plagioclase (Fig. 5) is less clearly aligned. Antiperthite, possibly of replacement origin, may constitute up to $40 \%$ of the plagioclase grains as laths or welldefined patches, but is generally absent. Quartz occurs as $100-300 \mu \mathrm{m}$ inclusions in plagioclase and less commonly in hornblende, but also as $200-600 \mu \mathrm{m}$ grains in the matrix. Larger grains in the matrix show undulose extinction, whereas rounded inclusions appear undeformed. Myrmekite is common along grain boundaries with K-feldspar and larger antiperthite patches, with up to $20 \mu \mathrm{m}$-wide quartz vermicules. Inclusions of zircon, clinozoisite, and titanite are common in hornblende, and less common in plagioclase. Clinozoisite is zoned, with cores showing yellow birefringence and blue birefringent rims, and is commonly surrounded (moreso than zircon) by pleochroic halos. Clinozoisite and titanite also occur as matrix minerals, with titanite oriented parallel to the foliation. A few biotite and plagioclase grains are situated inside the older quartz veins running parallel to the main foliation. This plagioclase is antiperthitic and weakly altered to sericite and coarser muscovite.

The first sign of retrograde alteration is the alteration of hornblende to biotite-quartz symplectites (Fig. 6A). $\mathrm{K}$-feldspar disappears, and plagioclase is weakly altered to calcite. Calcite commonly has a dusty appearance 

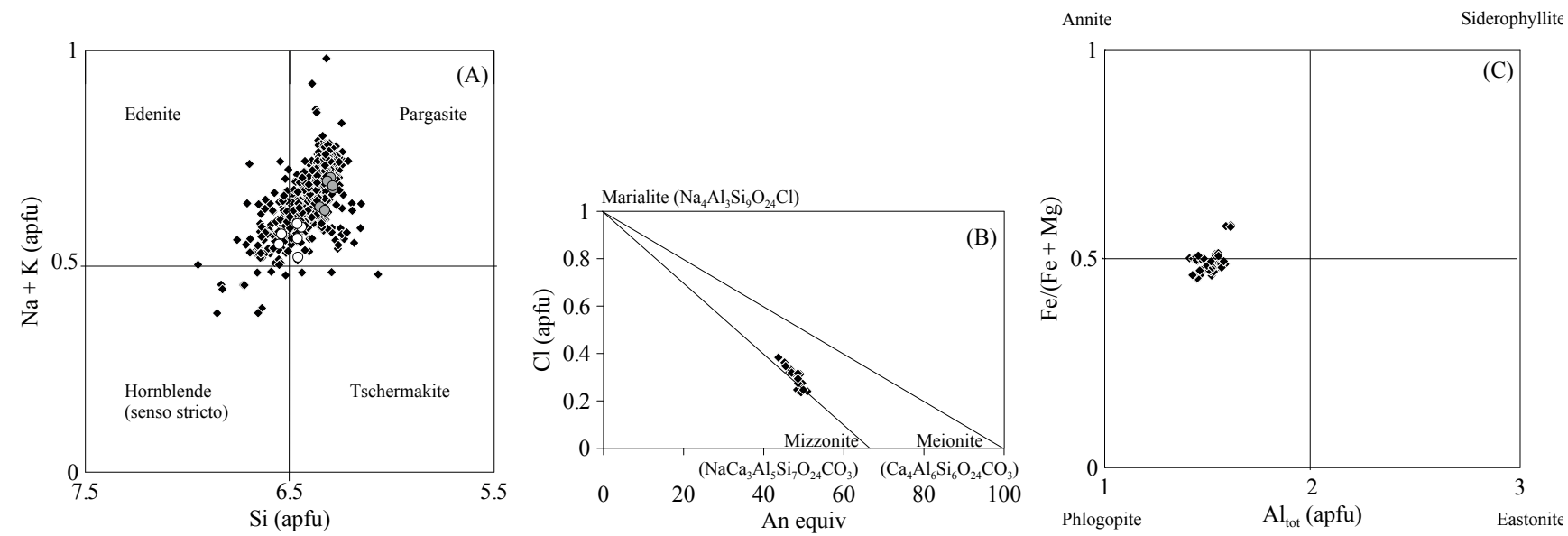

Figure 4. Classification of central minerals from EPMA analyses. (A) Amphibole compositions from the hornblende schist. White and grey circles are rim and core compositions used for P-T modeling. (B) Scapolite classification based on $\mathrm{Cl}$ content and anorthite equivalents. (C) Biotite compositions based on total $\mathrm{Al}$ and $\mathrm{Fe} /(\mathrm{Fe}+\mathrm{Mg})$ ratio.

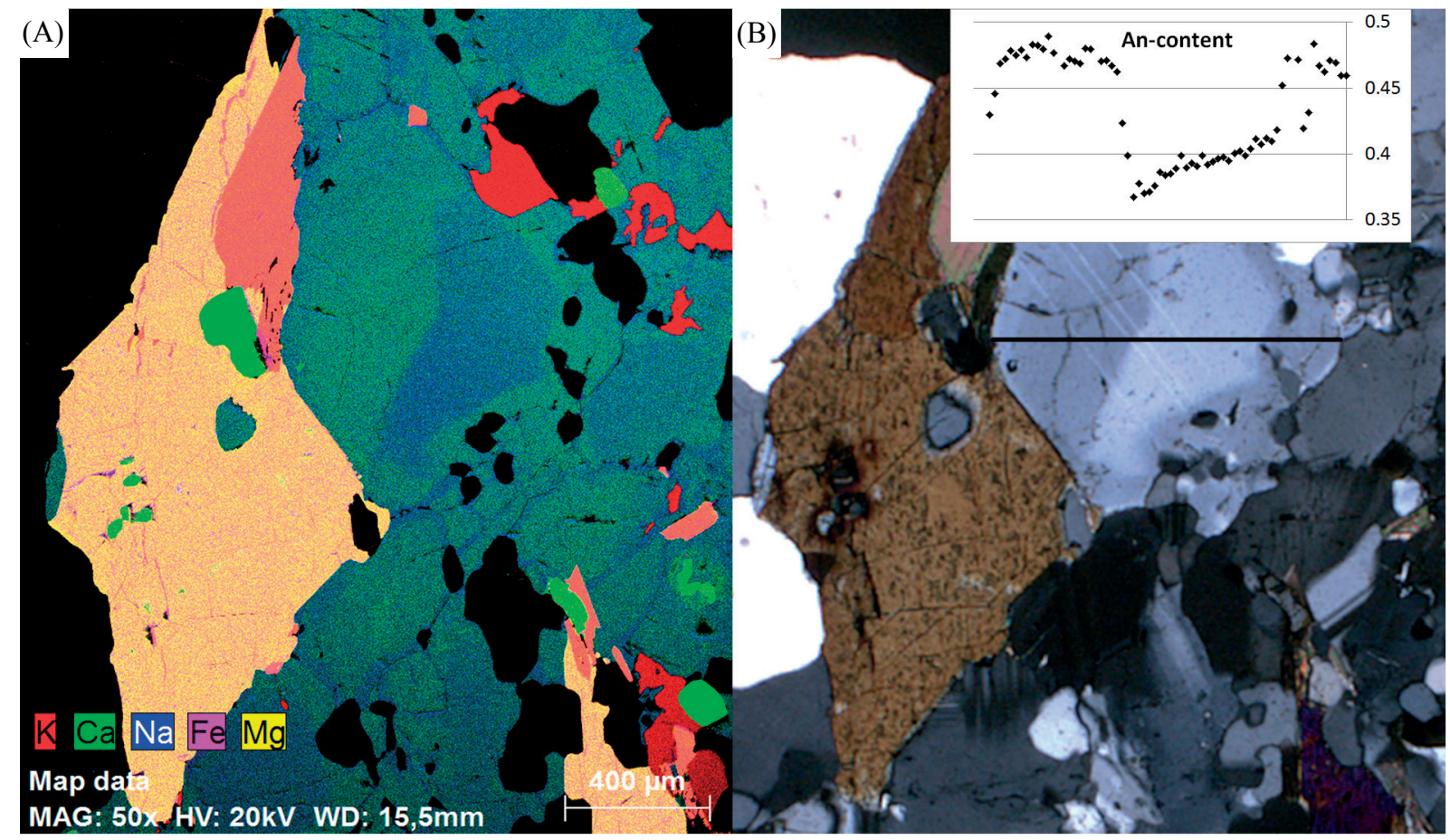

Figure 5. (A) Color-coded SEM picture of reverse-zoned plagioclase. (B) Same as (A) in cross-polarized transmitted light. The insert shows the An content of the plagioclase grain along the black line.

due to microscopic Fe-oxide inclusions. This alteration occurs furthest from the vertical quartz veins in both the BSZ and the CMZ. Some samples showed a depletion zone between the unaltered schist and the alteration zones (Fig. 6G, H). This zone lacks amphibole, but without extra biotite, and consists mostly of quartz and feldspar, and similar amounts of biotite as the protolith.

\section{Biotite-scapolite zone}

Near the quartz vein, in the schist, mica grains change orientation by $90^{\circ}$ from schistosity-parallel to quartz vein-parallel. This area is dominated by biotite with a zone of scapolite bordering the vein. Biotite and scapo- lite grains accumulate in separate distinctive zones but are intergrown at the contact between the two zones. Here, plagioclase is mostly unaltered, only weakly altered to calcite. However, there are rare examples of partial replacement of plagioclase by scapolite $\left(\mathrm{Me}_{53-59}\right.$; Figs. $4 \mathrm{~B}$, 6B; Table 3).

Both the grain size and the mineral chemistry of the biotite in the alteration zone are similar to biotite in the unaltered schist, which plots in the phlogopite and annite areas in the biotite quadrilateral (Fig. 4C). Both biotite generations have low $\mathrm{Cl}$ contents $(<0.06 \mathrm{apfu})$. In addition to biotite-quartz symplectites, amphibole is altered 

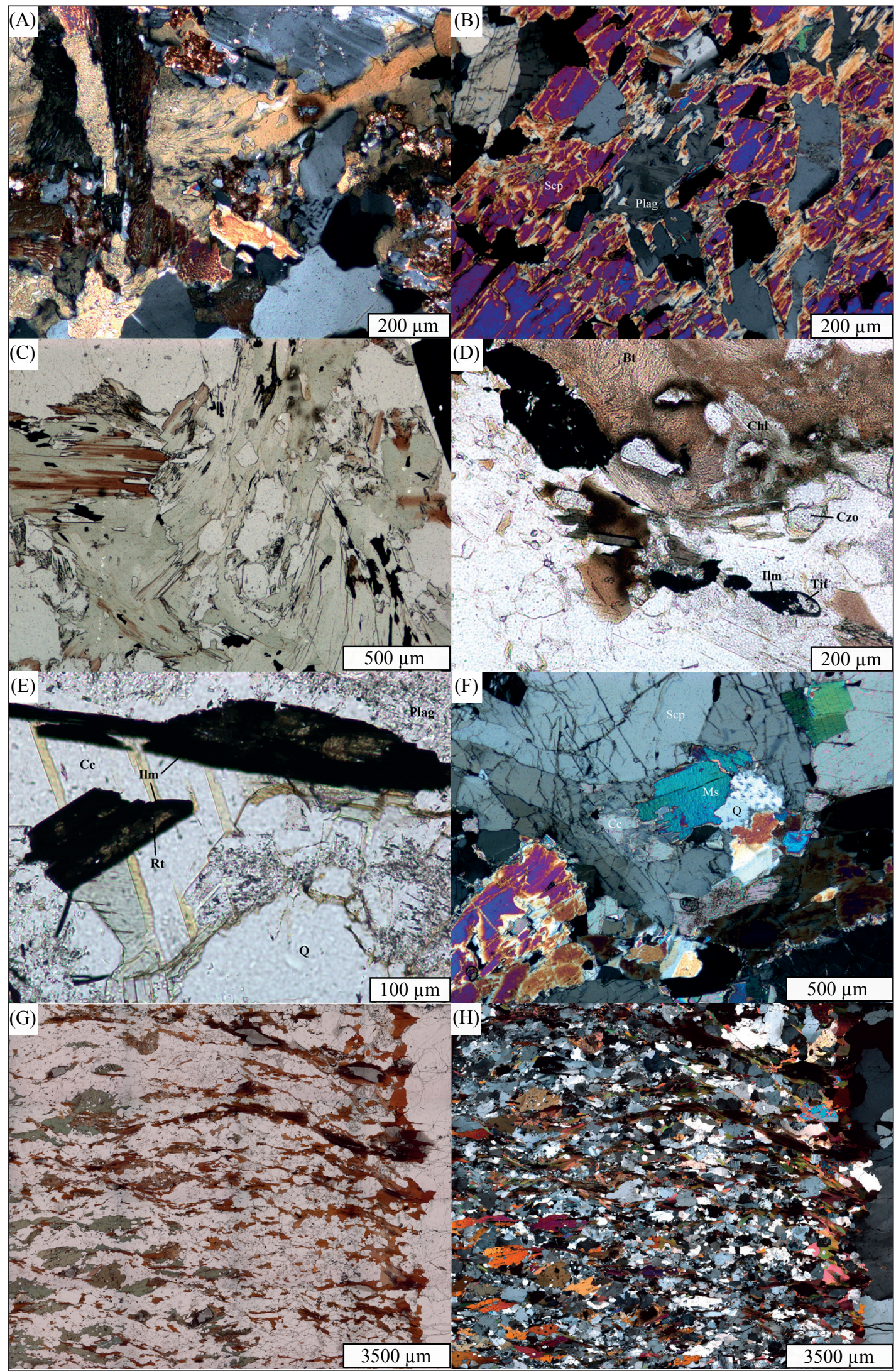

Figure 6. (A) Biotite-quartz symplectites after breakdown of amphibole. Cross-polarized transmitted light. (B) Partial replacement of plagioclase to scapolite in the biotite-scapolite zone. Cross-polarized transmitted light. (C) Direct replacement of biotite by chlorite and ilmenite in the chlorite subzone. Plane-polarized transmitted light. (D) Partial replacement of biotite by chlorite, and titanite by ilmenite. Located in the transition zone between the unaltered schist and the chlorite subzone. Plane-polarized transmitted light. (E) Ilmenite overgrowths on rutile in the CMZ. Plane-polarized transmitted light. (F) Partial replacement of scapolite to muscovite, calcite, and quartz in the scapolite subzone of the BSZ. Cross-polarized transmitted light. (G) Depletion zone between the unaltered schist (left) and minor biotite-scapolite alteration (right; the quartz vein is far right). Plane-polarized transmitted light. $(H)$ Same as $(G)$ but with cross-polarized transmitted light. 
Table 3. Average mineral compositions.

\begin{tabular}{|c|c|c|c|c|}
\hline$n$ & $\begin{array}{c}\text { Biotite }^{a} \\
44\end{array}$ & $\begin{array}{c}\text { Chlorite }^{b} \\
20\end{array}$ & $\begin{array}{c}\text { Muscovite }^{c} \\
18 \\
\end{array}$ & $\begin{array}{c}\text { Scapolite }^{d} \\
16\end{array}$ \\
\hline $\mathrm{SiO}_{2}$ & $37.12 \pm 1.32$ & $23.99 \pm 0.32$ & $49.17 \pm 0.32$ & $51.22 \pm 0.49$ \\
\hline $\mathrm{Al}_{2} \mathrm{O}_{3}$ & $16.90 \pm 0.58$ & $21.74 \pm 0.35$ & $33.13 \pm 0.57$ & $24.95 \pm 0.28$ \\
\hline $\mathrm{Na}_{2} \mathrm{O}$ & $0.13 \pm 0.05$ & $0.03 \pm 0.04$ & $0.49 \pm 0.07$ & $5.51 \pm 0.34$ \\
\hline $\mathrm{MgO}$ & $10.90 \pm 0.57$ & $13.17 \pm 0.29$ & $1.11 \pm 0.12$ & $<0.02$ \\
\hline $\mathrm{K}_{2} \mathrm{O}$ & $8.44 \pm 0.37$ & $<0.02$ & $8.14 \pm 0.27$ & $0.33 \pm 0.11$ \\
\hline $\mathrm{MnO}$ & $0.10 \pm 0.07$ & $0.03 \pm 0.03$ & $<0.02$ & $<0.02$ \\
\hline $\mathrm{TiO}_{2}$ & $2.43 \pm 0.28$ & $0.05 \pm 0.04$ & $0.22 \pm 0.12$ & $<0.02$ \\
\hline $\mathrm{CaO}$ & $0.04 \pm 0.05$ & $<0.02$ & $0.02 \pm 0.02$ & $13.35 \pm 0.46$ \\
\hline $\mathrm{FeO}$ (tot) & $18.80 \pm 1.53$ & $28.78 \pm 0.61$ & $1.87 \pm 0.25$ & $0.05 \pm 0.03$ \\
\hline $\mathrm{BaO}$ & $0.11 \pm 0.06$ & - & $0.14 \pm 0.06$ & - \\
\hline $\mathrm{Cl}$ & $0.27 \pm 0.11$ & - & $0.02 \pm 0.03$ & $1.18 \pm 0.17$ \\
\hline Total & $95.35 \pm 0.68$ & $88.02 \pm 0.90$ & $94.35 \pm 0.35$ & $96.42 \pm 0.34$ \\
\hline $\mathrm{Si}$ & $2.81 \pm 0.07$ & $2.58 \pm 0.03$ & $3.25 \pm 0.02$ & $7.72 \pm 0.05$ \\
\hline $\mathrm{Al}$ & $1.51 \pm 0.05$ & $2.75 \pm 0.05$ & $2.58 \pm 0.04$ & $4.43 \pm 0.06$ \\
\hline $\mathrm{Na}$ & - & - & $0.06 \pm 0.01$ & $1.61 \pm 0.09$ \\
\hline $\mathrm{Mg}$ & $1.23 \pm 0.06$ & $2.11 \pm 0.05$ & $0.11 \pm 0.01$ & - \\
\hline $\mathrm{K}$ & $0.81 \pm 0.03$ & - & $0.69 \pm 0.02$ & $0.06 \pm 0.02$ \\
\hline $\mathrm{Mn}$ & - & - & - & - \\
\hline $\mathrm{Ti}$ & $0.14 \pm 0.02$ & - & - & - \\
\hline $\mathrm{Ca}$ & - & - & - & $2.16 \pm 0.08$ \\
\hline $\mathrm{Fe}$ (tot) & $1.19 \pm 0.11$ & $2.58 \pm 0.04$ & $0.10 \pm 0.01$ & - \\
\hline $\mathrm{Ba}$ & $0.00 \pm 0.00$ & - & - & \\
\hline $\mathrm{Cl}$ & $0.03 \pm 0.01$ & - & - & $0.30 \pm 0.04$ \\
\hline $\mathrm{Fe} / \mathrm{Fe}+\mathrm{Mg}$ & $0.49 \pm 0.03$ & $0.55 \pm 0.01$ & & \\
\hline $\mathrm{Me}$ & & & & $0.56 \pm 0.02$ \\
\hline An eq & & & & $0.48 \pm 0.02$ \\
\hline
\end{tabular}

a Calculated based on 110

${ }^{b}$ Calculated based on 140

c Calculated based on 110

Calculated based on 16 cations

to a yellowish mineral. The alteration product was analyzed using three, large, defocused electron microprobe spots. They showed a mineral low in alkalies, and rich in $\mathrm{Fe}, \mathrm{Mg}, \mathrm{Al}$, and $\mathrm{Si}$. Totals were below $85 \%$, but this may be an indication of a more complex reaction. Ilmenite is the dominating Ti-phase, and is most easily observed in areas between hornblende breakdown and change in biotite orientation.

\section{Chlorite-muscovite-calcite zone (CMZ)}

The BSZ is overprinted by a mineral assemblage consisting of chlorite, muscovite, and calcite. This zone can be divided into two subzones, with chlorite replacing the former biotite zone, and muscovite and calcite replacing the scapolite-dominated zone. The CMZ penetrates further into the hornblende schist than the BSZ, and additional alteration of the wall rock has occurred during this stage. Partial replacement of biotite by chlorite (Fig. 6C) can be observed together with the formation of ilmenite at the expense of biotite and titanite while coexisting with clinozoisite (Fig. 6D). Ilmenite-rutile intergrowths (Fig. 6C) are more common closer to the vein, where chlorite replacement is more advanced. $\mathrm{Ti} \pm \mathrm{Fe}$-phases are more common in this zone than in the BSZ. Fe/(Fe $+\mathrm{Mg}$ ) ratios in biotite (average 0.49 ) are slightly lower than that in replacement chlorite (average 0.55). Plagioclase is sericitized to a much greater degree compared to the BSZ. Partial replacement of scapolite can also be observed (Fig. 6F), but in most thin-sections scapolite is absent in the CMZ.

\section{Fluid inclusions}

Three types of primary fluid inclusions are observed: Liquid (L) $\mathrm{CO}_{2}$ inclusions (type I); liquid-vapor (LV) $\mathrm{H}_{2} \mathrm{O}$ inclusions (type II); and liquid-vapor-solid (LVS) $\mathrm{NaCl}-\mathrm{H}_{2} \mathrm{O}-\mathrm{CO}_{2}$ inclusions (type III). Effort was made to distinguish between apparently primary fluid inclusions in separate clusters from secondary fluid inclusions clearly associated with fractures, and microthermometric measurements were performed only on primary fluid inclusions. Microthermometric results are summarized in Table 4.

Types I and II

Scapolite hosts mainly type I inclusions, but a few type II inclusions were found to coexist with type I fluid inclusions (Fig. 7A). Both type I and type II occur commonly in quartz, and are generally small $(<20 \mu \mathrm{m})$. Most type I inclusions are single-phase at room temperature, and homogenize into liquid at average $21^{\circ} \mathrm{C}$. Type II fluid inclusions are two-phase inclusions at room temperature with 5-10 vol.\% vapor (Fig. 7B). Average total homogenization $\left(\mathrm{LV} \rightarrow \mathrm{L}\right.$ ) for type II inclusions was $325^{\circ} \mathrm{C}$. Freezing point depressions for type II inclusions were 0.5 to $1.0^{\circ} \mathrm{C}$,

Table 4. Summary of microthermometric results.

\begin{tabular}{lcccc}
\hline Associated alteration assemblage & Fluid type & Fluid components & Reaction & Average temperature $\left({ }^{\circ} \mathrm{C}\right)$ \\
\hline $\mathrm{Chl}+\mathrm{ms}+\mathrm{cc}$ & III & $\mathrm{H}_{2} \mathrm{O}+\mathrm{NaCl} \pm \mathrm{CO}_{2} \pm \mathrm{CH}_{4}$ & Th $(\mathrm{LV}-\mathrm{L})$ & 469 \\
$\mathrm{Chl}+\mathrm{ms}+\mathrm{cc}$ & III & $\mathrm{H}_{2} \mathrm{O}+\mathrm{NaCl} \pm \mathrm{CO}_{2} \pm \mathrm{CH}_{4}$ & Th $(\mathrm{LV}-\mathrm{L})$ & 257 \\
$\mathrm{Chl}+\mathrm{ms}+\mathrm{cc}$ & $\mathrm{III}$ & $\mathrm{H}_{2} \mathrm{O}+\mathrm{NaCl} \pm \mathrm{CO}_{2} \pm \mathrm{CH}_{4}$ & Tm hal & 284 \\
$\mathrm{Bt}+\mathrm{scp}$ & II & $\mathrm{H}_{2} \mathrm{O}$ & Tm ice & -0.7 \\
$\mathrm{Bt}+\mathrm{scp}$ & II & $\mathrm{H}_{2} \mathrm{O}$ & Th $(\mathrm{LV}-\mathrm{L})$ & 325 \\
$\mathrm{Bt}+\mathrm{scp}$ & $\mathrm{I}$ & $\mathrm{CO}_{2}$ & Th $(\mathrm{LV}-\mathrm{L})$ & 21 \\
\hline
\end{tabular}




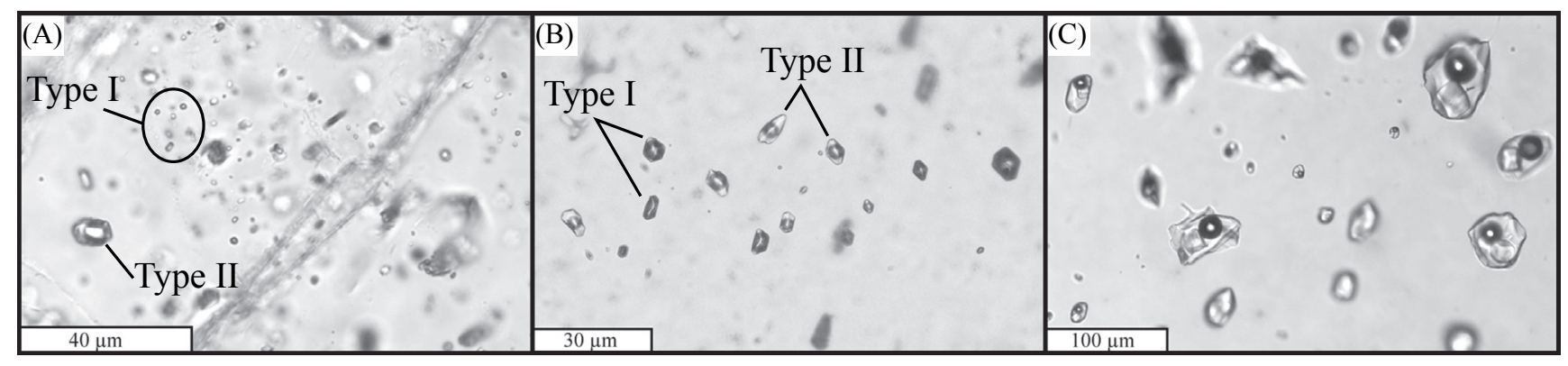

Figure 7. (A) Coexisting type I and II fluid inclusions in scapolite. (B) Coexisting type I and II fluid inclusions in quartz. (C) Type III inclusions in quartz.

yielding a salinity of $1-2$ mass $\% \mathrm{NaCl}$ equiv. using the equations from Bodnar (1993). Type II inclusions were measured in a quartz grain inside the chlorite zone free of type III inclusions.

\section{Type III}

Type III inclusions (Fig. 7C) are large (10-150 $\mu \mathrm{m}$ in the long direction), three phase (LVS) inclusions, only observed in quartz associated with chlorite-muscovite alteration. Multiple solid inclusions in addition to the halite crystal were observed, one of which was analyzed by Raman and verified as calcite. These solids vary in size and frequency, and are thus interpreted to be accidentally trapped minerals. Multiple melting and homogenization events occurred during heating from -195 to ca. $600^{\circ} \mathrm{C}$, indicating a complex fluid composition. A solid, likely ice, appeared in and around the bubble between -91 and $-88^{\circ} \mathrm{C}$, gradually deforming the bubble to a maximum at $-70^{\circ} \mathrm{C}$. The solid phase gradually melted and disappeared entirely between -45 and $-37^{\circ} \mathrm{C}$. In a few samples a birefringent, second, solid phase nucleated around accidentally trapped minerals, and melted between -25 and $-28^{\circ} \mathrm{C}$. The halite crystal dissolved between 250 and $331^{\circ} \mathrm{C}$, mostly between 270 and $305^{\circ} \mathrm{C}$ (Fig. 8B). Homogenization temperatures $(\mathrm{LV} \rightarrow \mathrm{L})$ showed a bimodal distribution with one group homogenizing mainly from 465 to $495^{\circ} \mathrm{C}$, and another group homogenizing before or at halite dissolution, mainly from 235 to $285^{\circ} \mathrm{C}$. Several inclusions decrepitated prior to homogenization, generally from $350^{\circ} \mathrm{C}$ and up, and during analyses of specific fluid inclusions, groups of nearby inclusions were observed to homogenize from $420^{\circ} \mathrm{C}$ and up. These are not listed in the histogram, since precise homogenization temperatures are not known, and the high-temperature group is thus underrepresented in the histogram (Fig. 8A). The birefringent, low-temperature solids were only observed in inclusions with high homogenization temperatures. Differences in halite dissolution could not be distinguished between the two groups, and $\mathrm{Tm}_{(\text {hal) }}$ for both groups contributes to the peak in the histogram. Using the equation of Sterner et al. (1988), the dissolution of the halite crystal gives a salinity of 37.4 mass $\% \mathrm{NaCl}$ equiv., calculated for the median $\mathrm{Tm}_{\text {(hal) }}$ of $289^{\circ} \mathrm{C}$ in the $\mathrm{H}_{2} \mathrm{O}-\mathrm{NaCl}$ system. The slope of the isochore for the low-temperature type III inclusions should be steeper in the liquid-halite $(\mathrm{L}-\mathrm{H})$ field than in the one-phase field (Bodnar, 1994), but as the salinity is fairly close to the pressure independent halite liquidus at 50 mass\% $\mathrm{NaCl}$ (Bodnar, 1994), and $\mathrm{Th}_{(\mathrm{LV}-\mathrm{L})}$ is within a few tens of degrees of $\mathrm{Tm}_{\text {(hal) }}$, errors in isochore calculations for the group that homogenize by halite dissolution are small, and thus ignored. Combined measurements of both $\mathrm{Tm}_{\text {(ice) }}$ and $\mathrm{Tm}_{\text {(hal) }}$ are limited, but calculating the fluid composition for the range of $\mathrm{Tm}_{\text {(ice) }}$ and median $\mathrm{Tm}_{\text {(hal) }}$ in the $\mathrm{H}_{2} \mathrm{O}-\mathrm{NaCl}-\mathrm{CaCl}_{2}$ system (Steele-MacInnis et al., 2011) yields a total salinity of 41.9-43.1 mass $\%$ $\left(\mathrm{NaCl}+\mathrm{CaCl}_{2}\right)$, and a molar $\mathrm{Na} / \mathrm{Ca}$ ratio between 1.8 and 2.1 .

In a few inclusions, $\mathrm{CO}_{2}$ melting could be observed from -60.6 to $-58.3^{\circ} \mathrm{C}$. Liquid-vapor homogenization of the carbonic phase was not observed, and density cannot be calculated, but the observed melting temperature close to the triple point of $\mathrm{CO}_{2}$ indicates a low $\mathrm{X}_{\mathrm{CH}_{4}}$, likely less than 0.2 (Thiery et al., 1994). Raman spectroscopic analyses of this generation of inclusions also indicated a minor $\mathrm{CH}_{4}$ component, but greater than in mixed $\mathrm{H}_{2} \mathrm{O}-\mathrm{CO}_{2}$ inclusions from the scheelite-bearing tremolite-diopside skarn in the W-Mo zone (Drivenes, 2010). Melting of $\mathrm{CO}_{2}$ was observed only in the low-Th $(\mathrm{LV}-\mathrm{L})$ inclusions.

Variation in the homogenization temperatures may result from stretching of the fluid inclusion during postentrapment decompression (e.g., Bodnar et al., 1989). However, the strongly bimodal $\mathrm{Th}_{(\mathrm{LV}-\mathrm{L})}$ distribution (Fig. $8 \mathrm{~A}$ ), uniform vapor volume, different $\mathrm{CO}_{2}$ content, and proposed near isobaric cooling history (see section 'Pressure and temperature constraints') indicate that the high $\mathrm{T}_{\mathrm{h}}$ fluids represent a fluid pulse infiltrating prior to the low $\mathrm{T}_{\mathrm{h}}$ fluids.

All isochores were calculated for the system $\mathrm{H}_{2} \mathrm{O}-\mathrm{NaCl}$, due to poorly constrained equations of state for gas-salt mixtures for salinities above the eutectic composition, and few observations of ice melting. Electron microprobe element maps of a selection of the decrepitated fluid inclusions showed elevated levels of $\mathrm{Na}, \mathrm{Ca}$, and $\mathrm{Fe}$, with less $\mathrm{K}$ and Mn. (Fig. 9). 

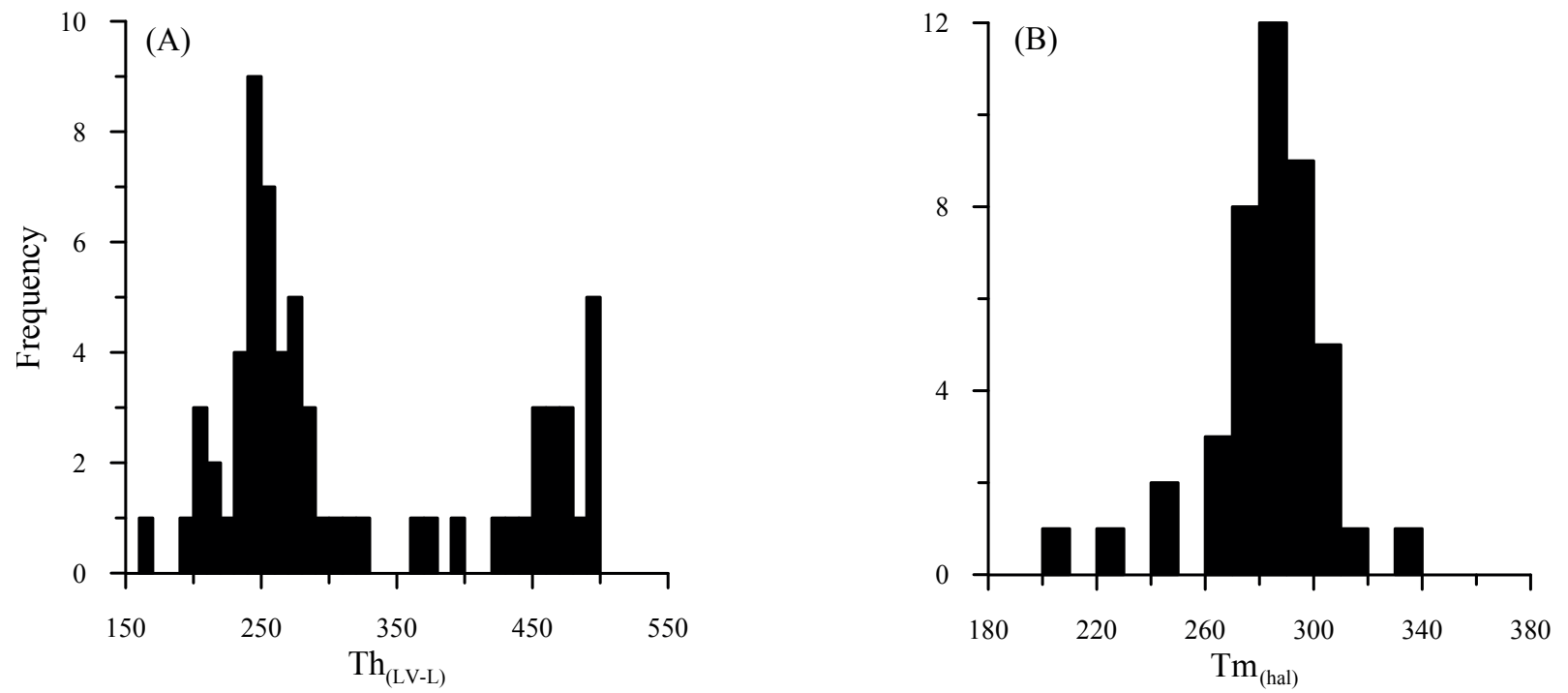

Figure 8. Histograms showing microthermometric analyses of type III fluid inclusions. (A) Liquid-vapor homogenization temperatures. (B) Halite dissolution temperatures.

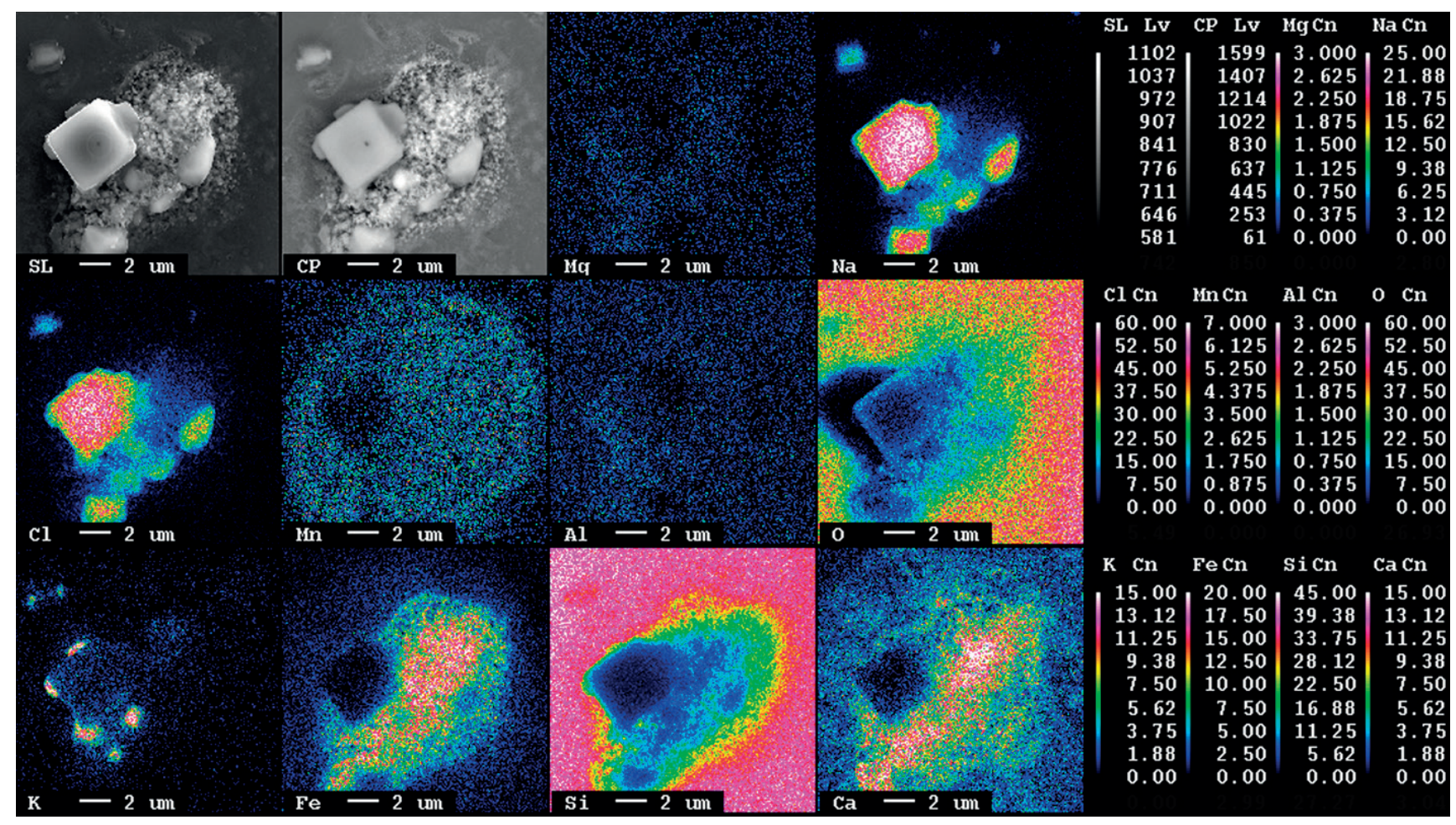

Figure 9. Element maps of surface condensates of a decrepitated type III fluid inclusion determined by EPMA. The numbers on the right are counts detected by the microprobe in the element maps, and intensity levels in the secondary electron and backscatter images.

\section{Mass exchange}

Isocon plots (Fig. 10; Grant, 1986, 2005) were drawn for the BSZ and CMZ alteration assemblages vs. the original hornblende schist. The two alteration assemblages were also plotted against each other. Overlap between the zones during sample preparation was unavoidable. Quartz and $\mathrm{Si}$ are thus not regarded in zones bordering the quartz vein due to cutting separation issues. In the isocon diagrams, the traditionally hydrothermally immobile element Zr (Finlow-Bates \& Stumpfl, 1981) is used as an isocon. Petrographic evidence also suggests that zircon is preserved during alteration (Fig. $6 \mathrm{C})$. When plotting the unaltered schist vs. the BSZ, the isocon intersected the $\mathrm{Al}$ point, indicating that $\mathrm{Al}$ was immobile during alteration. Since the muscovite-calcite and chlorite zones were analyzed separately, the combined CMZ was calculated under the presumption that $\mathrm{Al}$ also was immobile. That resulted in a mix consisting of ca. $2 / 3$ of the chlorite sample, and ca. 1/3 of the 

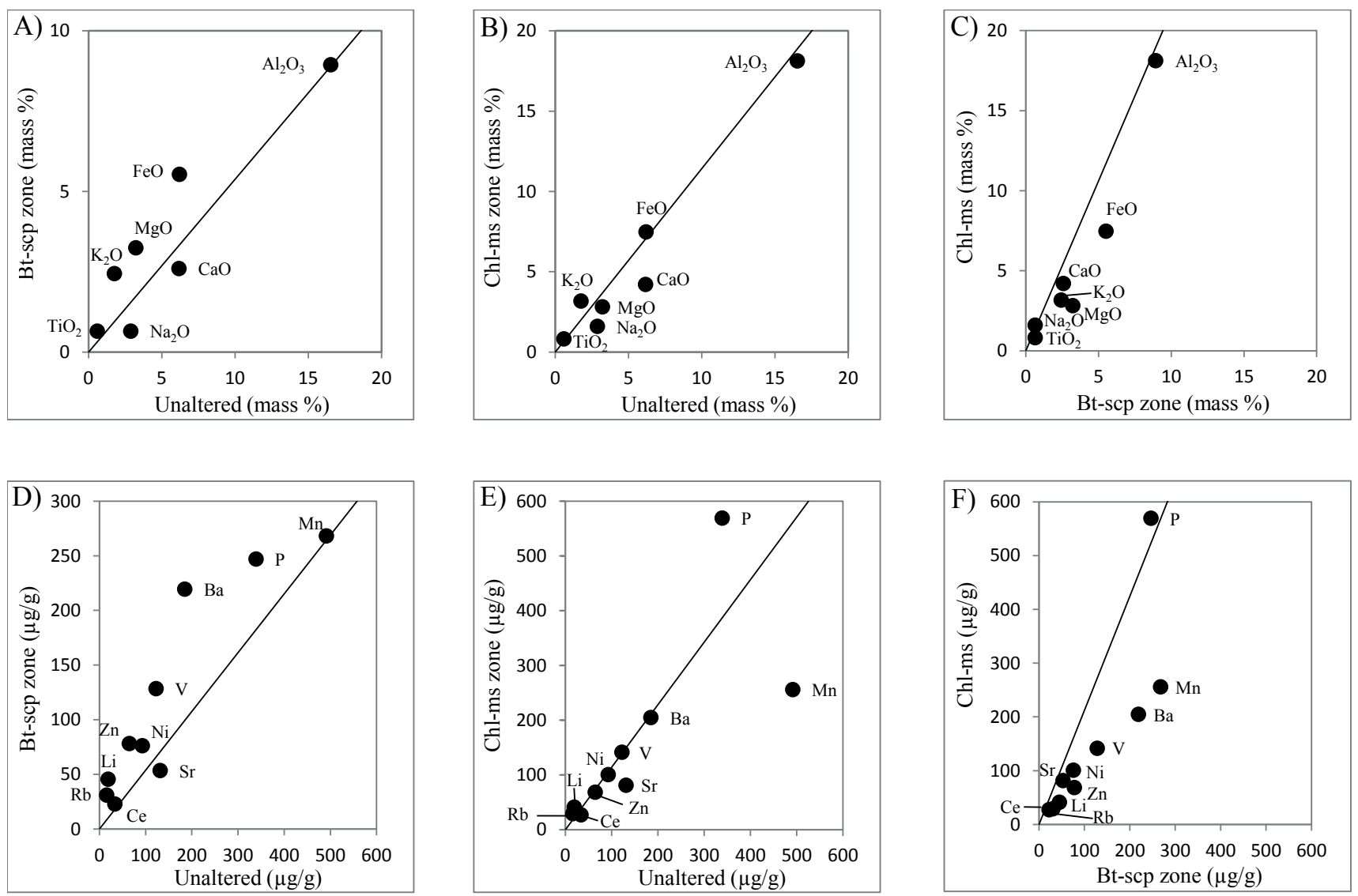

Figure 10. Isocon diagrams of the alteration zones plotted against the unaltered schist and each other, using Zr as isocon. (A-C) Major elements. (D-F) Trace elements.

muscovite-calcite sample. Only one sample of each zone was analyzed. Also, the extent of subzones within each alteration zone varies relative to each other (Fig. 3). This introduces further uncertainties in that the difference in chemical composition between the minerals within each zone will have an effect on the isocon plots. The results are thus used as indications for mass transfer, rather than statistical, quantitative implications for the complete system. The effects of variable mineral ratios are discussed in the subchapters dealing with the respective alteration assemblages. Both alteration assemblages are enriched in $\mathrm{K}$, and depleted in $\mathrm{Na}$ and $\mathrm{Ca}$ compared to the unaltered schist. The BSZ is also enriched in $\mathrm{Mg}, \mathrm{Fe}$, and $\mathrm{Ba}$, whereas the CMZ is depleted in Mn.

\section{Plagioclase-hornblende geothermometry}

Six pairs of adjacent hornblende and plagioclase grains were analyzed and used for plagioclase-hornblende geothermobarometry (Tables 5, 6). Traverses of point analyses with step size $10 \mu \mathrm{m}$ throughout the zoned plagioclase showed a distinct chemical zoning, correlated to the variations in extinction angle. Typical An contents in the rims vary from 0.45 to 0.47 , with core values from 0.37 to 0.43 (Fig. 5B; Table 5; Electronic Supplement 1). Orthoclase contents are less than 0.015 in the cores, and slightly lower in the rims. Hornblende is less drastically zoned, with $\Sigma \mathrm{Al}$ values from 2.01 to 2.14 apfu in the rims, and 2.29 to 2.36 in the cores (Table 6). Temperatures were estimated using the amphibole-plagioclase geothermometer (Blundy \& Holland, 1990; Holland \& Blundy, 1994), and pressure was calculated using Al-in-hornblende geobarometry (Johnson \& Rutherford, 1989). Combined, the thermobarometric calculations yielded P-T intervals from 678 to $708^{\circ} \mathrm{C}$ and 530 to $580 \mathrm{MPa}$ in the rims, and 680 to $704^{\circ} \mathrm{C}$ and 640 to $670 \mathrm{MPa}$ in the cores (Fig. 11).

\section{Discussion}

\section{Metamorphic and metasomatic reactions}

\section{Biotite-scapolite zone}

Based on petrographic observations, the replacement of calcic amphibole is controlled by the formation of new biotite, quartz, and minor calcite. In order to preserve stoichiometric balance, and given the limited amount of $\mathrm{K}$-feldspar available to react, $\mathrm{K}^{+}$has to be added. This can, to a certain degree, be canceled out by taking the alkali-depleted alteration product into account, assigning some of the $\mathrm{Fe}$ and $\mathrm{Mg}$ to that, and thus minimize the required $\mathrm{K}^{+}$. There are no Na-bearing alteration products 


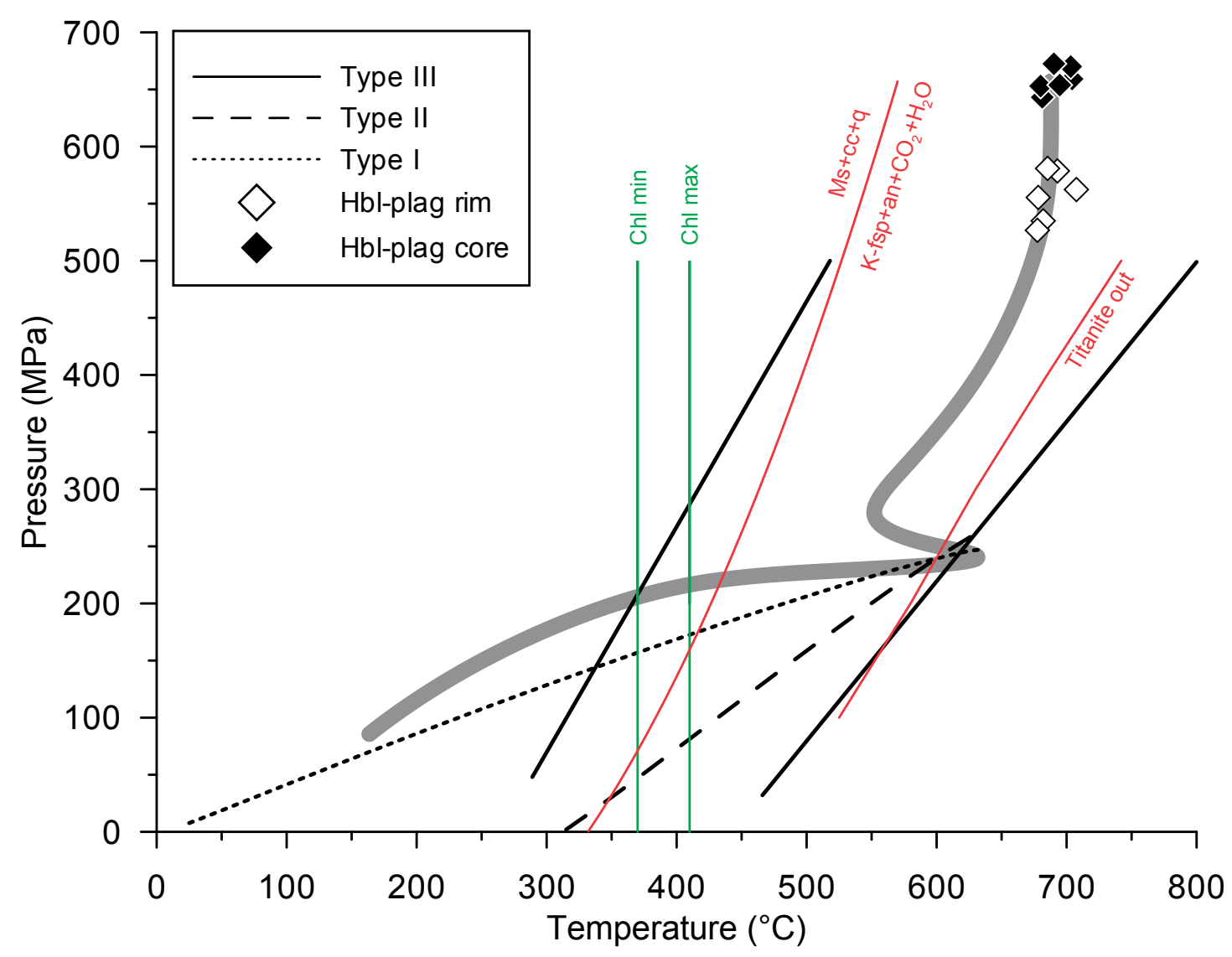

Figure 11. Summary of P-T estimates. The titanite-out line is from Spear (1981) at the QFM buffer. Upper stability of muscovite + calcite + quartz is extrapolated from data of Hewitt (1973) for XCO2 $=0.1$. Isochores for type I and II fluid inclusions are calculated using the BULK and ISOC programs of Bakker (2003), and type III are calculated from equations of Bodnar \& Vityk (1994) for a $\mathrm{H}_{2} \mathrm{O}-\mathrm{NaCl}$ fluid with 40 mass\% $\mathrm{NaCl}$. Minimum and maximum temperature of chlorite is calculated using the thermometer of Cathelineau (1988).

directly replacing amphibole. Scapolite is the only major host for $\mathrm{Na}$, but the extent of scapolite is not enough to accommodate the amount of $\mathrm{Na}^{+}$released at amphibole decomposition. Also, alteration of amphibole is observed several $\mathrm{cm}$ into the host schist, while scapolite is only recorded bordering the quartz vein, and a direct replacement of amphibole by scapolite is not observed. Newly formed albite was not observed, and the loss in $\mathrm{Na}_{2} \mathrm{O}$ in the BSZ (Fig. 10A) indicates that $\mathrm{Na}$ was extracted into the fluid phase. Given the phases observed in the unaltered protolith, the reaction may have been:

(1) Ca-amphibole $+\mathrm{K}$-feldspar $+\mathrm{H}_{2} \mathrm{O}+\mathrm{CO}_{2}\left(+\mathrm{K}^{+}{ }_{a q}\right) \rightarrow$ biotite + quartz $+\mathrm{Na}^{+}{ }_{\text {aq }} \pm$ calcite

Scapolite has replaced plagioclase close to the quartz vein. Meionite $0.53-0.59$ corresponds to anorthite equivalents $\left(\mathrm{An}_{\mathrm{eg}}\right)$ of $0.45-0.50$, coinciding roughly with the rim values of the original plagioclase, and serves as additional evidence for a direct replacement. Biotite is the main $\mathrm{Cl}$ bearing phase in the original rock, with much higher levels than amphibole, and since the original biotite coexists with scapolite, $\mathrm{Cl}$ in scapolite ( 0.3 apfu) has to originate from the fluid. Only minor calcite is observed, and it occurs only in areas where amphibole is altered. No carbonates are thus a major part of the protolith, and the $\mathrm{CO}_{3}^{+}$-component in scapolite is likely derived from the fluid. A possible reaction for the replacement could be as follows:

(2) Plagioclase $+\mathrm{CO}_{2}+\mathrm{Cl}_{\text {aq }}^{-} \rightarrow$ Scapolite

Scapolite composition is largely related to the infiltrating fluid (e.g., Orville, 1975; Ellis, 1978; Aitken, 1983), and although not completely carbonated, these scapolites must have been formed in contact with a low-salinity, $\mathrm{CO}_{2}$-dominated fluid.

Ilmenite coexists with Ti-bearing biotite, and examples of partial replacement of titanite by ilmenite can be observed (Fig. 6D). Rutile is scarce in samples which have not equilibrated with the high-salinity fluid, and commonly occurs in the zone between the chlorite zone and the unaltered zone. Titanite is the only Ti-phase that reacts out, and assuming $\mathrm{Fe}$ is available from amphibole breakdown, the main Ti reaction is:

(3) Titanite $+\mathrm{CO}_{2}+\mathrm{Fe}^{2+}{ }_{\text {aq }} \rightarrow$ ilmenite + quartz + calcite

Frost et al. (2001) suggested the breakdown of titanite, combined with amphibole dehydration, formed ilmen- 
Table 5. Plagioclase compositions used for thermobarometric calculations.

\begin{tabular}{|c|c|c|c|c|c|c|c|c|c|c|c|c|}
\hline \multirow[b]{2}{*}{ Grain } & \multicolumn{6}{|c|}{ Rim } & \multicolumn{6}{|c|}{ Core } \\
\hline & 1 & 2 & 3 & 4 & 5 & 6 & 1 & 2 & 3 & 4 & 5 & 6 \\
\hline $\mathrm{SiO}_{2}$ & 57.25 & 58.17 & 56.41 & 57.93 & 56.86 & 56.83 & 57.25 & 58.17 & 56.41 & 57.93 & 56.86 & 56.83 \\
\hline $\mathrm{Al}_{2} \mathrm{O}_{3}$ & 27.02 & 27.12 & 26.89 & 27.19 & 26.67 & 26.70 & 27.02 & 27.12 & 26.89 & 27.19 & 26.67 & 26.70 \\
\hline $\mathrm{FeO}$ & 0.05 & 0.09 & 0.14 & 0.08 & 0.08 & 0.06 & 0.05 & 0.09 & 0.14 & 0.08 & 0.08 & 0.06 \\
\hline $\mathrm{CaO}$ & 9.33 & 9.45 & 9.48 & 9.54 & 9.14 & 9.25 & 9.33 & 9.45 & 9.48 & 9.54 & 9.14 & 9.25 \\
\hline $\mathrm{Na}_{2} \mathrm{O}$ & 5.77 & 5.93 & 5.88 & 5.89 & 5.92 & 5.85 & 5.77 & 5.93 & 5.88 & 5.89 & 5.92 & 5.85 \\
\hline $\mathrm{K}_{2} \mathrm{O}$ & 0.13 & 0.19 & 0.16 & 0.16 & 0.16 & 0.14 & 0.13 & 0.19 & 0.16 & 0.16 & 0.16 & 0.14 \\
\hline Sum & 99.56 & 100.96 & 98.96 & 100.78 & 98.85 & 98.83 & 99.56 & 100.96 & 98.96 & 100.78 & 98.85 & 98.83 \\
\hline $\mathrm{Si}$ & 2.57 & 2.58 & 2.56 & 2.57 & 2.58 & 2.57 & 2.57 & 2.58 & 2.56 & 2.57 & 2.58 & 2.57 \\
\hline $\mathrm{Al}$ & 1.43 & 1.42 & 1.44 & 1.42 & 1.42 & 1.43 & 1.43 & 1.42 & 1.44 & 1.42 & 1.42 & 1.43 \\
\hline $\mathrm{Fe}$ (tot) & 0.00 & 0.00 & 0.01 & 0.00 & 0.00 & 0.00 & 0.00 & 0.00 & 0.01 & 0.00 & 0.00 & 0.00 \\
\hline $\mathrm{Ca}$ & 0.45 & 0.45 & 0.46 & 0.45 & 0.44 & 0.45 & 0.45 & 0.45 & 0.46 & 0.45 & 0.44 & 0.45 \\
\hline $\mathrm{Na}$ & 0.50 & 0.51 & 0.52 & 0.51 & 0.52 & 0.51 & 0.50 & 0.51 & 0.52 & 0.51 & 0.52 & 0.51 \\
\hline K & 0.01 & 0.01 & 0.01 & 0.01 & 0.01 & 0.01 & 0.01 & 0.01 & 0.01 & 0.01 & 0.01 & 0.01 \\
\hline An & 0.468 & 0.463 & 0.467 & 0.468 & 0.456 & 0.463 & 0.468 & 0.463 & 0.467 & 0.468 & 0.456 & 0.463 \\
\hline $\mathrm{Ab}$ & 0.524 & 0.526 & 0.524 & 0.523 & 0.534 & 0.529 & 0.524 & 0.526 & 0.524 & 0.523 & 0.534 & 0.529 \\
\hline Or & 0.008 & 0.011 & 0.009 & 0.009 & 0.010 & 0.009 & 0.008 & 0.011 & 0.009 & 0.009 & 0.010 & 0.009 \\
\hline
\end{tabular}

Structural formula calculated based on 80

Table 6. Amphibole compositions used for thermobarometric calculations.

\begin{tabular}{|c|c|c|c|c|c|c|c|c|c|c|c|c|}
\hline \multirow[b]{2}{*}{ Grain } & \multicolumn{6}{|c|}{ Rim } & \multicolumn{6}{|c|}{ Core } \\
\hline & 1 & 2 & 3 & 4 & 5 & 6 & 1 & 2 & 3 & 4 & 5 & 6 \\
\hline $\mathrm{SiO}_{2}$ & 43.52 & 42.91 & 42.95 & 43.13 & 43.35 & 43.63 & 42.25 & 41.95 & 42.08 & 41.66 & 42.19 & 41.60 \\
\hline $\mathrm{TiO}_{2}$ & 0.58 & 0.60 & 0.63 & 0.66 & 1.20 & 0.60 & 0.74 & 0.71 & 0.75 & 0.78 & 0.74 & 0.72 \\
\hline $\mathrm{Al}_{2} \mathrm{O}_{3}$ & 11.46 & 11.84 & 12.03 & 12.11 & 11.84 & 11.36 & 12.90 & 13.13 & 13.03 & 13.21 & 13.10 & 13.22 \\
\hline $\mathrm{FeO}$ & 18.03 & 18.49 & 18.32 & 18.24 & 18.18 & 18.05 & 18.44 & 18.53 & 18.61 & 18.70 & 18.54 & 18.33 \\
\hline $\mathrm{MnO}$ & 0.35 & 0.37 & 0.37 & 0.37 & 0.36 & 0.37 & 0.37 & 0.37 & 0.35 & 0.36 & 0.36 & 0.36 \\
\hline $\mathrm{MgO}$ & 9.18 & 9.22 & 8.83 & 8.95 & 9.30 & 9.22 & 8.51 & 8.60 & 8.45 & 8.32 & 8.65 & 8.54 \\
\hline $\mathrm{CaO}$ & 11.88 & 11.67 & 12.09 & 11.82 & 11.58 & 11.83 & 12.04 & 11.97 & 12.08 & 11.92 & 11.88 & 11.69 \\
\hline $\mathrm{Na}_{2} \mathrm{O}$ & 0.97 & 1.01 & 0.91 & 1.00 & 0.84 & 0.93 & 1.00 & 1.19 & 0.96 & 1.05 & 1.17 & 1.10 \\
\hline $\mathrm{K}_{2} \mathrm{O}$ & 1.48 & 1.50 & 1.50 & 1.56 & 1.41 & 1.41 & 1.76 & 1.84 & 1.78 & 1.90 & 1.84 & 1.85 \\
\hline $\mathrm{Cl}$ & 0.01 & 0.01 & 0.01 & 0.01 & 0.01 & 0.01 & 0.01 & 0.01 & 0.01 & 0.01 & 0.07 & 0.00 \\
\hline Sum & 97.45 & 97.62 & 97.64 & 97.86 & 98.06 & 97.41 & 98.02 & 98.29 & 98.10 & 97.91 & 98.54 & 97.41 \\
\hline $\mathrm{Si}$ & 6.54 & 6.44 & 6.46 & 6.46 & 6.46 & 6.55 & 6.35 & 6.30 & 6.33 & 6.29 & 6.32 & 6.29 \\
\hline $\mathrm{Al}^{\mathrm{IV}}$ & 1.46 & 1.56 & 1.54 & 1.54 & 1.54 & 1.45 & 1.65 & 1.70 & 1.67 & 1.71 & 1.68 & 1.71 \\
\hline $\mathrm{Al}^{\mathrm{VI}}$ & 0.57 & 0.54 & 0.60 & 0.60 & 0.54 & 0.56 & 0.64 & 0.62 & 0.64 & 0.64 & 0.63 & 0.65 \\
\hline $\mathrm{Ti}$ & 0.07 & 0.07 & 0.07 & 0.07 & 0.13 & 0.07 & 0.08 & 0.08 & 0.08 & 0.09 & 0.08 & 0.08 \\
\hline $\mathrm{Fe}^{3+}$ & 0.36 & 0.48 & 0.35 & 0.38 & 0.42 & 0.38 & 0.34 & 0.36 & 0.35 & 0.36 & 0.38 & 0.40 \\
\hline $\mathrm{Fe}^{2+}$ & 1.90 & 1.85 & 1.96 & 1.90 & 1.84 & 1.88 & 1.98 & 1.97 & 1.99 & 2.00 & 1.95 & 1.91 \\
\hline $\mathrm{Mn}$ & 0.05 & 0.05 & 0.05 & 0.05 & 0.04 & 0.05 & 0.05 & 0.05 & 0.04 & 0.05 & 0.05 & 0.05 \\
\hline $\mathrm{Mg}$ & 2.06 & 2.06 & 1.98 & 2.00 & 2.07 & 2.06 & 1.91 & 1.92 & 1.89 & 1.87 & 1.93 & 1.92 \\
\hline $\mathrm{Ca}$ & 1.91 & 1.88 & 1.95 & 1.90 & 1.85 & 1.90 & 1.94 & 1.93 & 1.95 & 1.93 & 1.91 & 1.89 \\
\hline $\mathrm{Na}$ & 0.28 & 0.29 & 0.27 & 0.29 & 0.24 & 0.27 & 0.29 & 0.35 & 0.28 & 0.31 & 0.34 & 0.32 \\
\hline $\mathrm{K}$ & 0.28 & 0.29 & 0.29 & 0.30 & 0.27 & 0.27 & 0.34 & 0.35 & 0.34 & 0.37 & 0.35 & 0.36 \\
\hline
\end{tabular}

Structural formula calcualted on basis of $23 \mathrm{O}$ 
ite and anorthite with increasing temperature in metabasites. In our samples, the titanite-out reaction occurs simultaneously with a hydration reaction of hornblende to biotite (Fig. 6D). It is more likely that ilmenite formed by a drop in pressure or reduction by fluid infiltration (Spear, 1981), or in fact, a combination of the two. However, a potential increase in temperature during ilmenite formation cannot be ruled out.

The isocon analysis for the BSZ shows a depletion in $\mathrm{Na}$ and $\mathrm{Ca}$, compared to the original rock (Fig. 10A). Loss of $\mathrm{Ca}$ and $\mathrm{Na}$ from amphibole breakdown may be the cause of this depletion. It is unlikely that the fluid responsible for the scapolitization was a pure $\mathrm{CO}_{2}-\mathrm{CH}_{4}$ fluid (Larsen, 1991), since mobilization of $\mathrm{Na}$ and $\mathrm{Ca}$ requires an aqueous component (e.g., Bai \& Koster van Groos, 1999). The increase in $\mathrm{K}, \mathrm{Mg}$, and $\mathrm{Fe}$ in this zone in the isocon plot may be a result of the specific sample having less than representative amounts of scapolite. The ratio between the biotite and scapolite contents is highly variable, and since $\mathrm{K}, \mathrm{Mg}$ and Fe are major components in biotite, and only occur as trace concentrations in scapolite, the increase in these elements may be artificially high in the isocon plot. Likewise, $\mathrm{Na}$ and $\mathrm{Ca}$ are major components in scapolite and trace components in biotite (Electronic Supplement 1 ), and would be closer to the isocon if the sample had more scapolite.

\section{Chlorite-muscovite zone}

In some samples, a gradual transition from the BSZ to the CMZ was observed. Here, chlorite replaces biotite, while scapolite is still stable (Fig. 12). This indicates that the overprinting has happened in variable degrees as a result of differing fluid/rock ratios. The remaining titanite, although restricted, is also altered to ilmenite during this fluid pulse. Ilmenite intergrowths with rutile are common, and rutile may also be an alteration product of ilmenite, possibly the result of Fe-leaching during the later stages. When the CMZ is plotted against the BSZ in the isocon diagram (Fig. 10C, F), the only significant change is a depletion in Fe and $\mathrm{Mg}$. The uncertainties regarding the representability of the BSZ sample discussed above also apply here, and $\mathrm{Fe}, \mathrm{Mg}$, and $\mathrm{K}$ may be over-represented in the BSZ, while $\mathrm{Na}$ and $\mathrm{Ca}$ are under-represented, and the depletion of $\mathrm{Mg}$ and $\mathrm{Fe}$ in the $\mathrm{CMZ}$ relative to the $\mathrm{BSZ}$ may be exaggerated. Likewise, $\mathrm{K}$ and $\mathrm{Ca}$ may be enriched in the $\mathrm{CMZ}$ relative to the BSZ. The petrographic observations (Fig. 6) indicate a two-step alteration, where biotite is altered to chlorite, and scapolite is altered to muscovite, calcite, and quartz. $\mathrm{The} \mathrm{Fe} /(\mathrm{Fe}+\mathrm{Mg})$ ratio for biotite and chlorite is similar, and the main resultant ion of the reaction is $\mathrm{K}^{+}$.

(4) Biotite (+ titanite $)+\mathrm{H}_{2} \mathrm{O} \rightarrow$ chlorite + ilmenite + quartz $+\mathrm{K}^{+}$
Closest to the vein, the replacement of scapolite by muscovite, calcite, and quartz requires $\mathrm{K}^{+}$and produces $\mathrm{Na}^{+}$and $\mathrm{Cl}^{-}$after the reaction:

(5) Scapolite $+\mathrm{H}_{2} \mathrm{O}+\mathrm{CO}_{2}+\mathrm{K}_{\text {aq }}^{+} \rightarrow$ muscovite + calcite + quartz $+\mathrm{NaCl}$

Seen as a whole, the overprinting of the BSZ can be written as:

(6) Scapolite + biotite $+\mathrm{H}_{2} \mathrm{O}+\mathrm{CO}_{2}+\mathrm{K}_{\text {aq }}^{+} \rightarrow$ Chlorite + ilmenite + muscovite + calcite + quartz $+\mathrm{NaCl}$

Whether $\mathrm{K}^{+}$is required in equation 6 depends on the ratio of $\mathrm{K}$-bearing alteration products (i.e., biotite and muscovite). However, plagioclase in the CMZ is more sericitized than in the BSZ, and it is our interpretation that $\mathrm{K}^{+}$was added during this fluid pulse. The net element budget for the complete metasomatic event is represented by the protolith vs. CMZ plot (Fig. 10B, E). The only element that is added during fluid infiltration is $\mathrm{K}$, and the protolith has thus experienced K-metasomatism. The CMZ extends further into the hornblende schist than the observed relics of the BSZ, and the bulk equation for the last metasomatic stage may have been:

(7) Plagioclase + biotite + hornblende + titanite + scapolite $+\mathrm{K}$-feldspar $+\mathrm{KCl}+\mathrm{H}_{2} \mathrm{O}+\mathrm{CO}_{2} \rightarrow$ Chlorite + muscovite + calcite $+(\mathrm{Fe})-\mathrm{Ti}$ oxide $+\mathrm{NaCl}+\mathrm{CaCl}_{2}$

The element exchange between the different zones is summarized in Fig. 12. As seen from the isocon diagrams, $\mathrm{Na}, \mathrm{Ca}, \mathrm{K}$, and $\mathrm{Mn}$ have been mobile elements in the system, as expected from their elevated levels in the fluid inclusions (Fig. 9). Additionally, there was a significant proportion of Fe in the type III fluids, but Fe did not increase in the altered rock.

\section{Fluid evolution and source}

All observed mineral reactions are fluid-driven, either as hydration, carbonation or other volatilization events. As a result, the newly formed mineral assemblages depend on the availability of volatiles. The close relationship between different fluid inclusions and the two different alteration zones implies that two separate fluid pulses interacted with the rock at different times. The lower-temperature mineral assemblage in the CMZ, its greater extent in the lower parts compared with the upper parts of the fracture system, and textural overprinting places this alteration later on the timeline. The close affiliation of high-salinity type III fluid inclusions to the CMZ, and the lack of these fluids in the BSZ, where only types I and II fluid inclusions occur, implies that alteration to the BSZ served as a preparatory stage for the main metasomatic event of the CMZ observed in the field. 


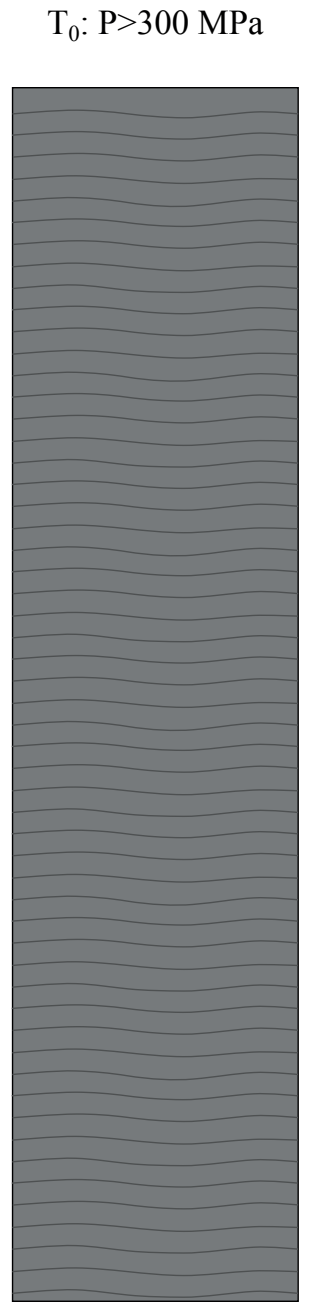

$$
\begin{aligned}
\mathrm{T}_{1}: \mathrm{T} \sim 600^{\circ} \mathrm{C} \\
\mathrm{P} \sim 240 \mathrm{MPa}
\end{aligned}
$$
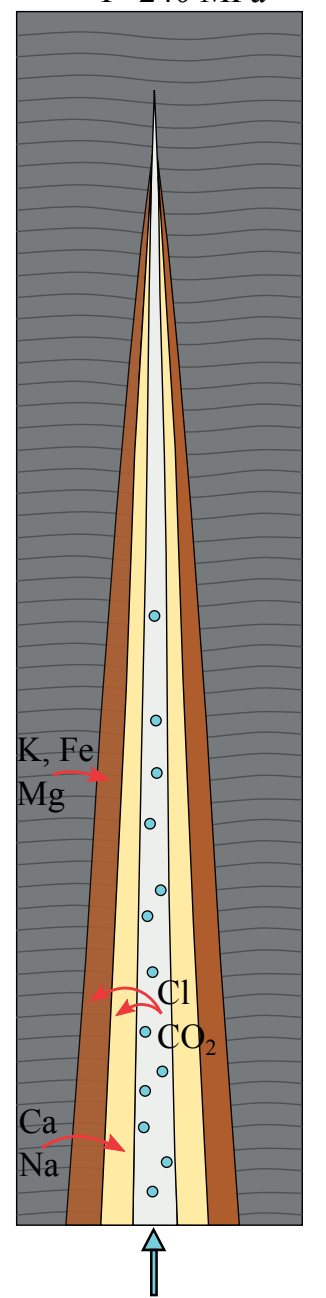

Infiltration of type I and II fluids.

Formation of the BSZ
$\mathrm{P} \sim 240 \mathrm{MPa}$

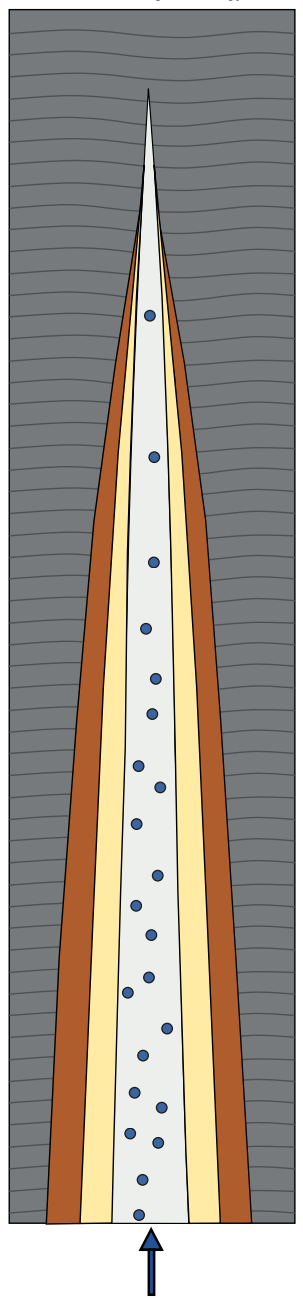

Start of infiltration of type III fluids

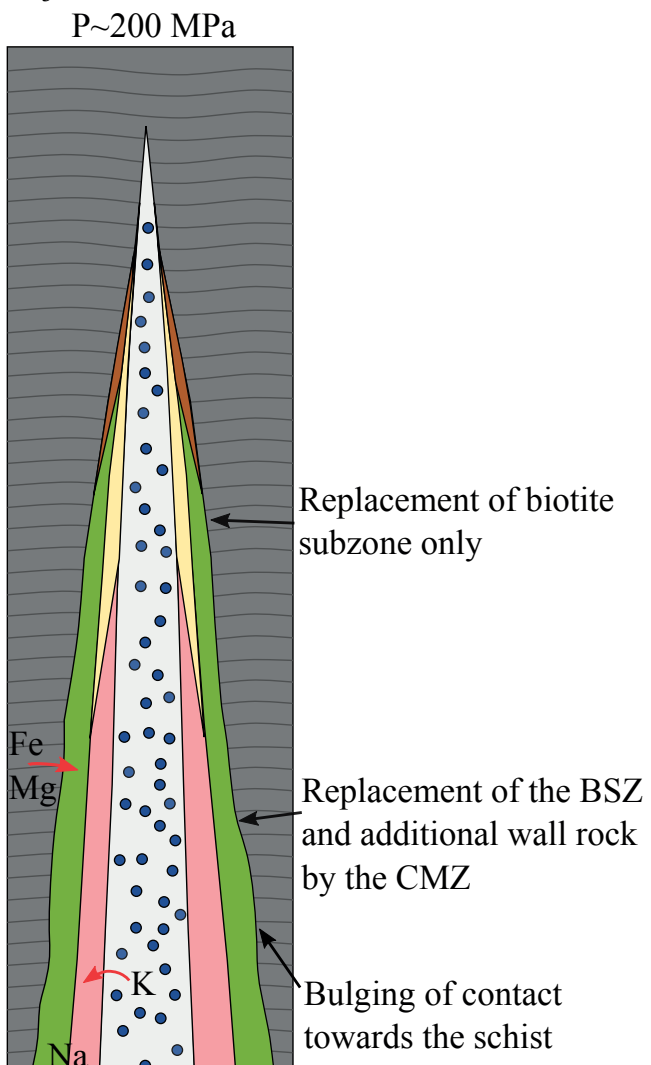

Hornblende schist

Quartz vein
Biotite subzone

Chlorite subzone

\section{Scapolite subzone}

Muscovite-calcite subzone

Figure 12. Overview of the metasomatic evolution during fluid influx.

For types I and II fluids to exist as separate inclusions, trapping must have occurred in the two-phase field. The intersection between the two isochores is in the onephase field of the $\mathrm{CO}_{2}-\mathrm{H}_{2} \mathrm{O}$ system, but the addition of other volatiles will greatly expand the immiscibility field (Diamond, 2003). However, it cannot be ruled out that the two inclusion types represent different fluid pulses. Type III inclusions, given their uniform volumetric liquid and vapor distribution, were trapped in the one-phase field. In addition, the fluid inclusions that homogenized by halite dissolution, cannot have been trapped in equilibrium with a vapor phase (Bodnar, 1994), excluding the evolution of a moderately saline fluid to a high-salinity fluid through phase separation (e.g., Burnham, 1979; Hedenquist \& Lowenstern, 1994; Ulrich et al., 2001).

Trapping of fluid inclusions that homogenize by halite dissolution and LV-L may be due to a rapid drop in temperature after fluid infiltration during near isobaric conditions. Systems with fluid populations that homogenize in similar fashion as in our study have been described from magmatic-hydrothermal ore deposits, such as the Bismark $\mathrm{Pb}-\mathrm{Zn}$ skarn deposit, Mexico (Baker \& Lang, 2003). A hot fluid pumped into a relatively cool host rock will lead to rapid cooling of the fluid system, given that it is not a long-lived system. This is implied from 
the hydrothermal overprinting being restricted to the lower parts of the fracture system, and only penetrating a few $\mathrm{cm}$ into the hornblende schist. The trapping conditions of types I and II inclusions are $600^{\circ} \mathrm{C}$ and 240 $\mathrm{MPa}$, whereas the minimum pressure and temperature for trapping of low-temperature type III inclusions are ca. $50 \mathrm{MPa}$ and $290^{\circ} \mathrm{C}$, where the isochore intersects the halite liquidus. This gives a gentle slope between the two events in the P-T diagram, especially if the type III fluid inclusions with low homogenization temperatures were trapped further up along the isochore.

The oxidation state of the low-salinity fluid is probably close to the QFM buffer, since the titanite-out curve in P-T space (Fig. 11) for the QFM buffer goes through the intersection of the isochores of the types I and II fluids, and ilmenite is stable instead of hematite.

The $\mathrm{pH}$ of a fluid in the $\mathrm{H}_{2} \mathrm{O}-\mathrm{CO}_{2}-\mathrm{NaCl}$ system decreases with increasing pressure and salinity, and increases with increasing temperature ( $\mathrm{Li} \&$ Duan, 2007). Also, the high-salinity fluid was apparently in equilibrium with muscovite instead of K-feldspar, indicating a low to moderate $a_{\mathrm{K}+} / a_{\mathrm{H}+}$ ratio (Bowers et al., 1984). The $\mathrm{K}$ content of the fluid was significant (Fig. 9), giving a low $\mathrm{pH}$. If a hot, acidic, and reactive fluid, such as the type III fluid, was to be transported over a great distance, it probably would have been buffered by the host rocks, including marble and other carbonate-bearing rocks, thus loosing much of its metasomatic potential. Alternatively, it could also have been transported from the source through a refractory channel. It is more likely that the fluid source was relatively local and that the fluids were far from equilibrium with the host. High-salinity fluids have not been observed in any other lithology in the metasedimentary stratigraphy (Larsen, 1988, 1991), and this fluid pulse was not pervasive, unlike $\mathrm{CO}_{2}-\mathrm{H}_{2} \mathrm{O}$ fluids, which are found as inclusions in most of the studied rocks from the area (Larsen, 1988, 1991; Drivenes, 2010). The sheared appearance of the lower part of the vein system indicates a tectonic contact, and the high-salinity fluids may have flowed through the shear zone from the source, and reused the already existing vein set. Alternatively, the hornblende schist was thrusted onto the underlying garnet-mica schist after fluids had altered the hornblende schist.

Metamorphic fluids with salinities resembling those of the type III fluids may form from evaporites (Yardley, 2013), but they are also commonly described as originating from S-type, granitic magmas (e.g., Lowenstern, 1994; Sirbescu \& Nabelek, 2003; Drivenes et al., 2016). Evaporites are not common in the Norwegian Caledonides, although meta-evaporitic magnesite and scapolite deposits have been described from the Skipa formation in the Swedish part of the Seve Nappe (Svenningsen, 1994). Also, if evaporates had been deposited along with the abundant carbonate bodies on the Laurentian continental margin, evidence of high-salinity fluids should be much more widespread than what has been observed. A possible source of the type III fluids observed could be a granitic body formed by decompression melting during rapid exhumation. Further rise of the granitic body would cause contact-metamorphic dehydration and decarbonation of the surrounding metasedimentary rocks and carbonates, forming the type I and type II fluids. A high-salinity fluid may later have been exsolved from the crystallizing magma to form the type III fluids. The $\mathrm{CO}_{2}$-dominated fluids responsible for the BSZ are not likely to have exsolved directly from an underlying magmatic source due to the low solubility of $\mathrm{CO}_{2}$ in felsic melts at pressures below 2 GPa (e.g., Fogel \& Rutherford, 1990; Blank et al., 1993; Guillot \& Sator, 2011). On the contrary, $\mathrm{CO}_{2}$-rich fluids are common in high-grade metamorphic rocks (Touret \& Nijland, 2013), and the multiple marble and carbonate-bearing bodies in the area could be likely sources of $\mathrm{CO}_{2}$. Also, fluids similar to those of types I and II, are common in the retrograde alteration of the surrounding metasedimentary rocks, and a magmatic body is not a prerequisite for these fluids. No high-salinity fluid inclusions have been observed in the pegmatite intruding the metasedimentary sequence, or in the quartz veins closely associated with the pegmatite, thus rendering the pegmatite an unlikely source. The low $\mathrm{Cl}$ content of the hornblende schist makes it unlikely for an originally low-salinity fluid to have reached the salinities of the type III fluids through metamorphic reactions. The fluid may have increased in salinity due to water consumption into the hydrous minerals, but we argue that the initial type III fluid was $\mathrm{Cl}$-rich prior to infiltration.

\section{Pressure and temperature constraints}

The highest recorded pressure and temperature in the rock is calculated from the cores of hornblende and plagioclase. Typical high-temperature minerals, such as pyroxene and wollastonite, are not observed. Hence, the temperatures of $\mathrm{ca} .700^{\circ} \mathrm{C}$ from plagioclase-hornblende thermometry are interpreted to represent the peak temperature of the system during regional metamorphism. The highest pressures are calculated from Al-in-hornblende barometry (Fig. 11), indicating a near-isothermal pressure drop, and thus a rapid uplift in the early retrograde stage.

End-member meionite is stable above $875^{\circ} \mathrm{C}$ (Goldsmith \& Newton, 1977), while $\mathrm{Me}_{83}$ (Aitken, 1983) and $\mathrm{Me}_{75}$ (Oterdoom \& Gunter, 1983), both $\mathrm{CO}_{3}$-scapolites, have been determined to be stable for $\mathrm{T}>625$ and $550^{\circ} \mathrm{C}$, respectively, in contact with $\mathrm{CO}_{2}$-rich fluids. For $\mathrm{Cl}$ bearing scapolites there is a general decrease in $\mathrm{X}_{\mathrm{Cl}}$ and increase in $\mathrm{An}_{\mathrm{eq}}$ with increasing metamorphic grade, with local variations due to fluid composition (Mora \& Valley, 1989). The lowest-temperature scapolites form around $400^{\circ} \mathrm{C}$, and are the $\mathrm{Al}-\mathrm{Si}$ ordered with an $\mathrm{An}_{\text {eq }}$ of 33 (Oterdoom \& Wenk, 1983). At the time of scapolitization, 
titanite was altered to ilmenite, restricting the event to high temperatures (Fig. 11). Assuming $\mathrm{fO}_{2}$ was close to the QFM buffer, the intersection between the type I and II isochores and the titanite-out curve, at ca. $600^{\circ} \mathrm{C}$ and $240 \mathrm{MPa}$, gives us the temperature and pressure for the first fluid infiltration and scapolititzation. Similar temperature and pressure estimates can also be achieved when assuming that the types I and II inclusions did not form during immiscibility. Both types predate the high salinity pulse. The high homogenization temperatures for both type I and type II inclusions require a high trapping temperature (type II), and elevated trapping pressure (type I), given trapping conditions at higher $\mathrm{P}-\mathrm{T}$ than the formation of the CMZ.

The temperature estimates are well within the stability field of our analyzed scapolite, and in agreement temperature-wise with scapolites of similar composition from the kyanite-staurolite zone and kyanite-sillimanite zone of the Wallace formation, USA (Mora \& Valley, 1989), but at lower pressure in our example. Other examples of high-temperature scapolitization include Mary Kathleen, Mt Isa, Australia (Oliver et al., 1994) and the Bamble sector, Norway (Engvik et al., 2011). However, scapolite in both examples is considerably more marialitic than scapolites from Bjellatinden. These temperature and pressure estimates are also in agreement with the conclusions of Larsen (1991) for scapolite formation in a scheelite-bearing scapolite skarn.

Between the P-T points from plagioclase-hornblende thermobarometry and the scapolitization, no additional firm pressure or temperature constraints can be made. There are two possible paths to explain the uplift history: a near-isothermal pressure drop during rapid uplift and crustal thinning, or uplift along a less steep thermal gradient and reheating by a magmatic intrusion. In the first scenario, thermal lag during rapid exhumation would produce a steep P-T path during the early stage followed by a gently sloping cooling path. In the case of the second scenario, a magmatic heat source will create a significant isobaric temperature increase. Without an infiltrating fluid, the amphibolitic assemblage could have persisted well into greenschist facies before being reheated on a local scale by hot fluids causing scapolitization. A granitic body has not been observed, nor even a contact-metamorphic aureole. However, as discussed above, a magmatic intrusion is the most likely source for the high-salinity fluids, and an intrusion may also explain the P-T path during the late stages of the metamorphic history. The pegmatites in the area are rich in tourmaline, and given that the proposed underlying granitic magma had a similar composition, it could also have been B-rich. Boron suppresses the liquidus significantly, and a completely molten magma may not have been hotter than $750-800^{\circ} \mathrm{C}$ (Pichavant, 1987). Heat production from such a system would have been sufficient to induce both the scapolitization and the high-temperature type III fluids. Typical retrograde, post-intrusion $\mathrm{P}-\mathrm{T}$ paths are (near) isobaric cooling (Spear, 1995), similar to our path for Bjellatinden.

The mineral assemblage observed in the CMZ is not stable at the high temperatures of the high-temperature type III fluid group. At $200 \mathrm{MPa}$, the thermal maximum stability of muscovite + calcite + quartz is $475^{\circ} \mathrm{C}$ in contact with a $\mathrm{CO}_{2}-\mathrm{H}_{2} \mathrm{O}$ fluid with $\mathrm{X}_{\mathrm{CO}_{2}}$ of 0.5 (Hewitt, 1973). $\mathrm{X}_{\mathrm{CO}_{2}}$ of the high-salinity fluid is low, and the muscovite alteration occurred at lower temperatures. Extrapolation of the muscovite-calcite-quartz line to $\mathrm{X}_{\mathrm{CO}_{2}}=0.1$ gives temperatures of around 380 and $425^{\circ} \mathrm{C}$ for 100 and 200 $\mathrm{MPa}$, respectively. Tetrahedral-Al-in-chlorite thermometry (Cathelineau, 1988) gave temperatures from 370 to $410^{\circ} \mathrm{C}$, and although criticized (e.g., de Caritat et al., 1993), it may give an indication of the formation temperature for the $\mathrm{CMZ}$. Assuming a maximum pressure of $240 \mathrm{MPa}$, and using the chlorite temperatures, muscovite-calcite-quartz stability line and the isochore for the low-temperature type III fluids as boundaries, a limited window from $370^{\circ} \mathrm{C}$ and $75 \mathrm{MPa}$ to $410^{\circ} \mathrm{C}$ and $240 \mathrm{MPa}$ can be drawn for the formation of the CMZ.

\section{Implications for W-Mo mineralizations}

The model with an underlying granitic magma solves two major problems: The source of high-salinity fluids and the source of tungsten. The $\mathrm{W}$ content of the metasedimentary rocks is insignificant (Larsen, 1988), and these rocks are unlikely to have been leached of enough $\mathrm{W}$ to form the mineralizations in the area. As discussed earlier, the high-salinity type III fluids are also most likely magmatic in origin.

A granitic intrusion may have driven the hydrothermal convection system which eventually formed the mineralizations. Devolatilization of carbonates and pelites during an intrusive stage formed the metamorphic, lowsalinity, $\mathrm{CO}_{2}-\mathrm{H}_{2} \mathrm{O}$ fluids. These fluids interacted with the crystallizing granitoid intrusion, scavenging $\mathrm{W}$ and Mo, which subsequently allowed for the formation of the $\mathrm{W}(-\mathrm{Mo})$ veins and replacement mineralizations. When the magma reached water saturation, the exsolved, highsalinity fluids migrated through existing fractures and shear zones, and eventually overprinted the pre-existing mineral assemblage. The vein system in this study was barren, and occurred stratigraphically above the mineralized layers.

The sheared appearance of the lower parts of the quartz veins indicate significant shearing. The shear zone may have accommodated greater fluid flow compared to lithological and structural boundaries in the underlying units, which may explain why late high-salinity fluids are only observed in this particular zone. The main W mineralizations are strongly associated with marble units in the $\mathrm{W}-\mathrm{Mo}$ zone. $\mathrm{CO}_{2}$ inclusions in scapolite, related to the scheelite-mineralized scapolite skarn in 
the richest mineralized zone, have similar $\mathrm{T}_{h}$ as the type I inclusions in our study (Larsen, 1991). However, the mineralized zones are associated with the tapering and disappearance of marble bodies. The stability of scheelite was controlled by the availability of $\mathrm{Ca}^{2+}$ and $\mathrm{pH}$ (Wesolowski, 1984). The lack of Ca-carbonate bodies as a source of $\mathrm{Ca}^{2+}$ and $\mathrm{pH}$ buffering during breakdown, may have restricted scheelite precipitation in the studied lithology. Fluid inclusions associated with scheelite mineralization in the underlying diopside skarn body are mixed $\mathrm{H}_{2} \mathrm{O}-\mathrm{CO}_{2}$ fluids (Drivenes, 2010). These fluids are not observed in the vein system, and a clear relationship between the ore-forming event and the fluids observed in the quartz veins cannot be established. The source of $\mathrm{W}$ for the $\mathrm{W}$-mineralized diopside and garnet-diopside skarn from Målvika, Nordland, has been interpreted to be the W-enriched granites of the Visttindan massif up to $1 \mathrm{~km}$ away (Müller \& Furuhaug, 2008), implying that long-distance transportation of ore-bearing fluids in similar environments is not unique.

\section{Conclusions}

This study documents reactions during fluid-rock interaction in a hornblende schist where two fluid pulses have altered and metasomatized the original rock at different stages during amphibolite- to greenschist-facies metamorphism. The main aspects of the study can be summarized as:

1. Low-salinity, $\mathrm{CO}_{2}-\mathrm{H}_{2} \mathrm{O}$ fluids responsible for the breakdown of hornblende to biotite-quartz symplectites, the alteration of titanite to ilmenite, and of plagioclase to scapolite $\left(\mathrm{Me}_{53-59}\right)$, formed distinct biotite and scapolite zones. Alteration occurred at ca. $600^{\circ} \mathrm{C}$ and $240 \mathrm{MPa}$. Only minor element exchange occurred during this alteration.

2. High-salinity fluids overprinted the former alteration assemblage and extended further into the host rock, resulting in bulk K-metasomatism. Biotite is replaced by chlorite and ilmenite, and scapolite is altered to muscovite, calcite, and quartz. This alteration happened during cooling somewhere between $370^{\circ} \mathrm{C} ; 75$ $\mathrm{MPa}$, and $410^{\circ} \mathrm{C} ; 240 \mathrm{MPa}$.

3. The low-salinity fluids are of metamorphic origin, and are a part of the regional retrograde stage, whereas the high-salinity fluids were exsolved from an underlying S-type granitic magma and transported through local shear zones. These overprinted the existing alteration assemblage using the same vein system.

Acknowledgments. The manuscript to this paper forms part of the $\mathrm{PhD}$ thesis of KD. Reviews by Daniel Harlov and one anonymous reviewer greatly improved the final version of the manuscript.

\section{References}

Aitken, B.G. 1983: T-X $\mathrm{CO}_{2}$ stability relations and phase equillibria of calcic carbonate scapolite. Geochimica et Cosmochimica Acta 47, 351-362.

Andréasson, P.G. 1994: The Baltoscandian margin in neoproterozoicearly palaeozoic times. Some constraints on terrane derivation and accretion in the Arctic Scandinavian Caledonides. Tectonophysics 231, 1-32. doi: http://dx.doi.org/10.1016/0040-1951(94)90118-X.

Andresen, A. \& Steltenpohl, M.G. 1994: Evidence for ophiolite obduction, terrane accretion and polyorogenic evolution of the north Scandinavian Caledonides. Tectonophysics 231, 59-70. doi: http://dx.doi.org/10.1016/0040-1951(94)90121-X.

Appel, P.W.U. 1986: Strata bound scheelite in the Archean Malene supracrustal belt, West Greenland. Mineralium Deposita 21, 207215. doi: 10.1007/BF00199802.

Augland, L.E., Andresen, A., Corfu, F., Simonsen, S.L. \& Andersen, T. 2012: The Beiarn Nappe Complex: A record of Laurentian Early Silurian arc magmatism in the Uppermost Allochthon, Scandinavian Caledonides. Lithos 146-147, 233-252. doi: 10.1016/j.lithos.2012.05.016.

Bai, T.B. \& Koster van Groos, A.F. 1999: The distribution of Na, K, Rb, $\mathrm{Sr}, \mathrm{Al}, \mathrm{Ge}, \mathrm{Cu}, \mathrm{W}, \mathrm{Mo}, \mathrm{La}$, and Ce between granitic melts and coexisting aqueous fluids. Geochimica et Cosmochimica Acta 63, 11171131. doi: http://dx.doi.org/10.1016/S0016-7037(98)00284-1.

Baker, T. \& Lang, J. 2003: Reconciling fluid inclusion types, fluid processes, and fluid sources in skarns: an example from the Bismark Deposit, Mexico. Mineralium Deposita 38, 474-495. doi: 10.1007/s00126-002-0306-3.

Bakker, R.J. 2003: Package FLUIDS 1. Computer programs for analysis of fluid inclusion data and for modelling bulk fluid properties. Chemical Geology 194, 3-23.

Barbosa, F.L.M., Maranhao, R. \& de Mello, A.A. 1986: Tungsten deposits of Brazil. In Beus, A.A. (ed.): Geology of Tungsten/International Geological Correlation Programme, Project 26 "MAWAM", Earth Sciences 18, UNESCO, Paris, pp. 209-216.

Barker, A. 1986: The geology between Salangsdalen and Gratangenfjord, Troms, Norway. Norges geologiske undersøkelse Bulletin 405, 41-56.

Barnes, C.G., Frost, C.D., Yoshinobu, A.S., McArthur, K., Barnes, M.A., Allen, C.M., Nordgulen, Ø. \& Prestvik, T. 2007: Timing of sedimentation, metamorphism, and plutonism in the Helgeland Nappe Complex, north-central Norwegian Caledonides. Geosphere 3, 683703. doi: 10.1130 /ges00138.1.

Bergström, S. 1979: Whiterockian (Ordovician) conodonts from the Hølonda Limestone of the Trondheim Region, Norwegian Caledonides. Norsk Geologisk Tidsskrift 59, 295-307.

Blank, J.G., Stolper, E.M. \& Carroll, M.R. 1993: Solubilities of carbon dioxide and water in rhyolitic melt at $850^{\circ} \mathrm{C}$ and 750 bars. Earth and Planetary Science Letters 119, 27-36. doi: http://dx.doi. org/10.1016/0012-821X(93)90004-S.

Blundy, J.D. \& Holland, T.J.B. 1990: Calcic amphibole equilibria and a new amphibole plagioclase geothermometer. Contributions to Mineralogy and Petrology 104, 208-224.

Bodnar, R.J. 1993: Revised equation and table for determining the freezing point depression of $\mathrm{H}_{2} \mathrm{O}-\mathrm{Nacl}$ solutions. Geochimica et Cosmochimica Acta 57, 683-684. doi: http://dx.doi. org/10.1016/0016-7037(93)90378-A.

Bodnar, R.J. 1994: Synthetic fluid inclusions: XII. The system $\mathrm{H}_{2} \mathrm{O}-$ $\mathrm{NaCl}$. Experimental determination of the halite liquidus and isochores for a $40 \mathrm{wt} \% \mathrm{NaCl}$ solution. Geochimica et Cosmochimica Acta 58, 1053-1063. doi: http://dx.doi.org/10.1016/00167037(94)90571-1.

Bodnar, R. \& Vityk, M.O. 1994: Interpretation of microthermometric data for $\mathrm{H}_{2} \mathrm{O}-\mathrm{NaCl}$ fluid inclusions. In De Vivo, B. \& Frezzotti, M.L. (eds.): Fluid inclusions in minerals: methods and applications, Virginia Tech, Blacksburg, VA, pp. 117-130.

Bodnar, R.J., Binns, P.R. \& Hall, D.L. 1989: Synthetic fluid inclusions VI. Quantitative evaluation of the decrepitation behaviour of fluid 
inclusions in quartz at one atmosphere confining pressure. Journal of Metamorphic Geology 7, 229-242. doi: 10.1111/j.1525-1314.1989. tb00586.x.

Bowers, T.S., Jackson, K.J. \& Helgeson, H.C. 1984: Equilibrium activity diagrams: for coexisting minerals and aqueous solutions at pressures and temperatures to $5 \mathrm{~kb}$ and $600^{\circ} \mathrm{C}$. Springer Science \& Business Media, Berlin, $305 \mathrm{pp}$.

Bowitz-Ihlen, P. 1973: En malmgeologisk undersøkelse av scheelittmineraliseringene i strøket Ravanne - Øver Laksfors $i$ Vefsn. Diploma thesis, Norwegian Institute of Technology (NTH), 101 pp.

Braathen, A., Osmundsen, P.T., Nordgulen, O., Roberts, D. \& Meyer, G.B. 2002: Orogen-parallel extension of the Caledonides in northern Central Norway: an overview. Norsk Geologisk Tidsskrift 82, 225-242.

Bruton, D.L. \& Harper, D.A.T. 1988: Arenig-Llandovery stratigraphy and faunas across the Scandinavian Caledonides. Geological Society of London Special Publications 38, 247-268. doi: 10.1144/gsl. sp.1988.038.01.15.

Burnham, C.W. 1979: Magma and hydrothermal fluids. In Barnes, H.L. (ed.): Geochemistry of Hydrothermal Ore Deposits, Holt, Rinehard and Winston Inc., New York, pp. 71-136.

Caritat, P. de, Hutcheon, I. \& Walshe, J. 1993: Chlorite geothermometry: a review. Clays and Clay Minerals 41,219-239.

Cathelineau, M. 1988: Cation site occupancy in chlorites and illites as a function of temperature. Clay Minerals 23, 471-485.

Cribb, S.J. 1981: Rb-Sr geochronological evidence suggesting a reinterpretation of part of the north Norwegian Caledonides. Norsk Geologisk Tidsskrift 61, 97-110.

Diamond, L.W. 2003: Introduction to gas-bearing, aqueous fluid inclusions. Fluid Inclusions: Analysis and Interpretation 32, 101-158.

Drivenes, K. 2010: Tungsten mineralized diopside skarn in the Bjellatinden area: Petrology and fluid inclusion studies. MSc thesis, Norwegian University of Science and Technology, $138 \mathrm{pp}$.

Drivenes, K., Larsen, R.B., Müller, A. \& Sørensen, B.E. 2016: Crystallization and uplift path of late Variscan granites evidenced by quartz chemistry and fluid inclusions: Example from the Land's End granite, SW England. Lithos 252-253, 57-75. doi: http://dx.doi. org/10.1016/j.lithos.2016.02.011.

Eide, E., Osmundsen, P., Meyer, G. \& Kendrick, M. 2002: An ${ }^{40} \mathrm{Ar} /{ }^{39} \mathrm{Ar}$ geochronology profile through the Nesna shear zone, north-central Norway: a middle Devonian-Early Carboniferous ductile extension and unroofing record. Norwegian Journal of Geology 82, 317-339.

Ellis, D.E. 1978: Stability and phase equilibria of chloride and carbonate bearing scapolites at $750^{\circ} \mathrm{C}$ and 4000 bar. Geochimica et Cosmochimica Acta 42, 1271-1281.

Engvik, A.K., Mezger, K., Wortelkamp, S., Bast, R., Corfu, F., Korneliussen, A., Ihlen, P., Bingen, B. \& Austrheim, H. 2011: Metasomatism of gabbro - mineral replacement and element mobilization during the Sveconorwegian metamorphic event. Journal of Metamorphic Geology 29, 399-423. doi: 10.1111/j.1525-1314.2010.00922.x.

Finlow-Bates, T. \& Stumpfl, E.F. 1981: The behavior of socalled immobile elements in hydrothermally altered rocks associated with volcanogenic submarine-exhalative ore deposits. Mineralium Deposita $16,319-328$.

Fogel, R.A. \& Rutherford, M.J. 1990: The solubility of carbon dioxide in rhyolitic melts; a quantitative FTIR study. American Mineralogist $75,1311-1326$

Frost, B.R., Chamberlain, K.R. \& Schumacher, J.C. 2001: Sphene (titanite): phase relations and role as a geochronometer. Chemical Geology 172, 131-148. doi: http://dx.doi.org/10.1016/S00092541(00)00240-0.

Gee, D.G., Fossen, H., Henriksen, N. \& Higgins, A.K. 2008: From the Early Paleozoic latforms of Baltica and Laurentia to the Caledonide orogen of Scandinavia and Greenland. Episodes 31, 44-51.

Gibert, F., Moine, B., Schott, J. \& Dandurand, J.-L. 1992: Modeling of the transport and deposition of tungsten in the scheelite-bearing calc-silicate gneisses of the Montagne Noire, France. Contribu- tions to Mineralogy and Petrology 112, 371-384. doi: 10.1007/ BF00310467.

Goldsmith, J. \& Newton, R. 1977: Scapolite-plagioclase stability relations at high pressures and temperatures in the system NaAlSi 3 O 8-CaAl 2 Si 2 O 8-CaCO 3-CaSO 4. American Mineralogist 62, 1063-1081.

Grant, J.A. 1986: The isocon diagram; a simple solution to Gresens' equation for metasomatic alteration. Economic Geology 81, 1976-1982.

Grant, J.A. 2005: Isocon analysis: A brief review of the method and applications. Physics and Chemistry of the Earth, Parts $A / B / C$ 30, 997-1004. doi: 10.1016/j.pce.2004.11.003.

Grenne, T., Ihlen, P.M. \& Vokes, F.M. 1999: Scandinavian Caledonide Metallogeny in a plate tectonic perspective. Mineralium Deposita 34, 422-471. doi: 10.1007/s001260050215.

Guillot, B. \& Sator, N. 2011: Carbon dioxide in silicate melts: A molecular dynamics simulation study. Geochimica et Cosmochimica Acta 75, 1829-1857. doi: http://dx.doi.org/10.1016/j.gca.2011.01.004.

Gustavson, M. 1996: Geologisk kart over Norge. Berggrunnskart SULITJELMA, Scale 1:250,000, Norges geologiske undersøkelse.

Gustavson, M. \& Gjelle, S. 1991: Geologisk kart over Norge. Berggrunnskart Mo i Rana, Scale 1:250, 000, Norges geologiske undersøkelse

Hedenquist, J.W. \& Lowenstern, J.B. 1994: The role of magmas in the formation of hydrothermal ore deposits. Nature 370, 519-527.

Hewitt, D.A. 1973: Stability of the assemblage muscovite-calcitequartz. American Mineralogist 58, 785-791.

Holland, T.J.B. \& Blundy, J.D. 1994: Non-ideal interactions in calcic amphiboles and their bearing on amphibole plagioclase thermometry. Contributions to Mineralogy and Petrology 116, 433-447.

Hollingworth, S., Wells, M. \& Bradshaw, R. 1960: Geology and structure of the Glomfjord region, northern Norway. Proceedings of the 21st International Geological Congress 19, Copenhagen, Denmark, pp. 33-42.

Holmes, M. 1966: Structure of the area north of Ørnes, Nordland, Norway. Norges geologiske undersøkelse 242, 62-93.

Johnson, M.C. \& Rutherford, M.J. 1989: Experimental calibration of the aluminum-in-hornblende geobarometer with application to Long Valley caldera (California) volcanic rocks. Geology 17, 837841. doi: 10.1130/0091-7613(1989)017<0837:ecotai>2.3.co;2.

Larsen, R.B. 1988: Wolframmineraliseringer i Bjellåtind området, NordNorge. MSc thesis, University of Copenhagen, $111 \mathrm{pp}$.

Larsen, R.B. 1991: Tungsten skarn mineralizations in a regional metamorphic terrain in northern Norway: a possible metamorphic ore deposit. Mineralium Deposita 26, 281-289.

Larsen, R.B., Eide, E.A. \& Burke, E.A.J. 1998: Evolution of metamorphic volatiles during exhumation of microdiamond-bearing granulites in the Western Gneiss Region, Norway. Contributions to Mineralogy and Petrology 133, 106-121. doi: 10.1007/s004100050441.

Larsen, O., Skar, O. \& Pedersen, R.-B. 2002: U-Pb zircon and titanite geochronological constraints on the late/post-Caledonian evolution of the Scandinavian Caledonides in north-central Norway. Norsk Geologisk Tidsskrift 82, 1-14.

Li, D. \& Duan, Z. 2007: The speciation equilibrium coupling with phase equilibrium in the $\mathrm{H}_{2} \mathrm{O}-\mathrm{CO}_{2}-\mathrm{NaCl}$ system from 0 to $250^{\circ} \mathrm{C}$, from 0 to $1000 \mathrm{bar}$, and from 0 to 5 molality of $\mathrm{NaCl}$. Chemical Geology 244, 730-751. doi: http://dx.doi.org/10.1016/j.chemgeo.2007.07.023.

Lowenstern, J.B. 1994: Chlorine, fluid immiscibility, and degassing in peralkaline magmas from Pantelleria, Italy. American Mineralogist 79, 353-369.

Melezhik, V., Gorokhov, M., Fallick, A., Roberts, D., Kuznetsov, A., Zwaan, K. \& Pokrovsky, B. 2002: Isotopic stratigraphy suggests Neoproterozoic ages and Laurentian ancestry for high-grade marbles from the North-Central Norwegian Caledonides. Geological Magazine 139, 375-393.

Melezhik, V.M., Zwaan, B.K., Motuza, G., Roberts, D., Solli, A., Fallick, A.E., Gorokhov, I.M. \& Kusnetzov, A.B. 2003: New insights into the geology of high-grade Caledonian marbles based on isotope che- 
mostratigraphy. Norwegian Journal of Geology 83, 209-242.

Mora, C.I. \& Valley, J.W. 1989: Halogen-rich scapolite and biotite: Implications for metamorphic fluid-rock interaction. American Mineralogist 74, 721-737.

Müller, A. \& Furuhaug, L. 2008: Resource evaluation of the Målvika tungsten deposit, Nordland. Norges geologiske undersøkelse Report 2008.008, 49 pp.

Nordgulen, O., Braathen, A., Corfu, F., Osmundsen, P.T. \& Husmo, T. 2002: Polyphase kinematics and geochronology of the late-Caledonian Kollstraumen detachment, north-central Norway. Norsk Geologisk Tidsskrift 82, 299-316.

Oliver, N.H., Rawling, T.J., Cartwright, I. \& Pearson, P.J. 1994: Hightemperature fluid-rock interaction and scapolitization in an extension-related hydrothermal system, Mary Kathleen, Australia. Journal of Petrology 35, 1455-1491.

Orville, P.M. 1975: Stability of scapolite in the system Ab-An-NaCl$\mathrm{CaCO}_{3}$ at $4 \mathrm{~kb}$ and $750^{\circ} \mathrm{C}$. Geochimica et Cosmochimica Acta 39, 1091-1105. doi: http://dx.doi.org/10.1016/0016-7037(75)90052-6.

Osmundsen, P.T., Braathen, A., Nordgulen, Ø., Roberts, D., Meyer, G.B. \& Eide, E. 2003: The Devonian Nesna shear zone and adjacent gneiss-cored culminations, North-Central Norwegian Caledonides. Journal of the Geological Society 160, 137-150. doi: 10.1144/0016-764901-173.

Oterdoom, W.H. \& Gunter, W.D. 1983: Activity models for plagioclase and $\mathrm{CO}_{3}$ scapolites - An analysis of field and laboratory data. American Journal of Science 283-A, 255-282.

Oterdoom, W.H. \& Wenk, H.-R. 1983: Ordering and composition of scapolite: Field observations and Structural interpretations. Contributions to Mineralogy and Petrology 83,330-341.

Pichavant, M. 1987: Effects of $\mathrm{B}$ and $\mathrm{H}_{2} \mathrm{O}$ on liquidus phase relations in the haplogranite system at $1 \mathrm{kbar}$. American Mineralogist 72, 1056-1070.

Roberts, D. 2003: The Scandinavian Caledonides: event chronology, palaeogeographic settings and likely modern analogues. Tectonophysics 365, 283-299. doi: 10.1016/s0040-1951(03)00026-x.

Roberts, D. \& Gee, D. 1985: An introduction to the structure of the Scandinavian Caledonides. The Caledonide orogen-Scandinavia and related areas $1,55-68$.

Roberts, D., Melezhik, V.M. \& Heldal, T. 2002: Carbonate formations and early NW-directed thrusting in the highest allochthons of the Norwegian Caledonides: evidence of a Laurentian ancestry. Journal of the Geological Society 159, 117-120. doi: 10.1144/0016-764901-128.

Roberts, D., Nordgulen, Ø. \& Melezhik, V.M. 2007: The uppermost allochthon in the Scandinavian Caledonides: From a Laurentin ancestry through Taconian orogeny to Scandian crustal growth on Baltica. The Geological Society of America Memoirs 200, 357-377. doi: 10.1130/2007.1200(18.

Rutland, R.W.R. \& Nicholson, R. 1965: Tectonics of the Caledonides of part of Nordland, Norway. Quarterly Journal of the Geological Society 121, 73-109. doi: 10.1144/gsigs.121.1.0073.

Sirbescu, M.-L.C. \& Nabelek, P.I. 2003: Crystallization conditions and evolution of magmatic fluids in the Harney Peak Granite and associated pegmatites, Black Hills, South Dakota-Evidence from fluid inclusions. Geochimica et Cosmochimica Acta 67, 2443-2465. doi: http://dx.doi.org/10.1016/S0016-7037(02)01408-4.

Skaarup, P. 1974: Strata-bound scheelite mineralisation in skarns and gneisses from the Bindal area, Northern Norway. Mineralium Deposita 9, 299-308. doi: 10.1007/BF00206633.

Skår, Ø. 2002: U-Pb geochronology and geochemistry of early Proterozoic rocks of the tectonic basement windows in central Nordland, Caledonides of north-central Norway. Precambrian Research 116, 265-283.

Skår, Ø. \& Pedersen, R.B. 2003: Relations between granitoid magmatism and migmatization: $\mathrm{U}-\mathrm{Pb}$ geochronological evidence from the Western Gneiss Complex, Norway. Journal of the Geological Society 160, 935-946. doi: 10.1144/0016-764901-121.

Smith, M.P. \& Yardley, B.W.D. 1999: Fluid evolution during metamorphism of the Otago Schist, New Zealand: (I) Evidence from fluid inclusions. Journal of Metamorphic Geology 17, 173-186. doi: 10.1046/j.1525-1314.1999.00189.x.

Spear, F.S. 1981: An experimental study of hornblende stability and compositional variability in amphibolite. American Journal of Science 281, 697-734. doi: 10.2475/ajs.281.6.697.

Spear, F.S. 1995: Metamorphic phase equilibria and pressure-temperaturetime paths. Mineralogical Society of America, Washington, 799 pp.

Spjeldnæs, N. 1985: Biostratigraphy of the Scandinavian Caledonides. In Gee, D.G. \& Sturt, B.A. (eds.): The Caledonide Orogen-Scandinavia and Related Areas, John Wiley \& Sons, Ltd., Chichester, pp. 317-329.

Steele-MacInnis, M., Bodnar, R.J. \& Naden, J. 2011: Numerical model to determine the composition of $\mathrm{H}_{2} \mathrm{O}-\mathrm{NaCl}-\mathrm{CaCl}_{2}$ fluid inclusions based on microthermometric and microanalytical data. Geochimica et Cosmochimica Acta 75, 21-40. doi: http://dx.doi.org/10.1016/j. gca.2010.10.002.

Stendahl, H., Furuhaug, L., Korneliussen, A. \& Larsen, R.B. 1993: Wolframmineraliseringer i Bodø-Glomfjord-regionen. Norges geologiske undersøkelse Report 92.231,33 pp.

Stephens, M.B. 1988: The Scandinavian Caledonides: a complexity of collisions. Geology Today 4, 20-26. doi: 10.1111/j.1365-2451.1988. tb00537.x.

Stephens, M. \& Gee, D. 1985: A tectonic model for the evolution of the eugeoclinal terranes in the central Scandinavian Caledonides. In Gee, D.G. \& Sturt, B.A. (eds.): The Caledonide Orogen-Scandinavia and Related Areas, John Wiley \& Sons, Ltd., Chichester, 953-978.

Stephens, M., Gustavson, M., Ramberg, I. \& Zachrisson, E. 1985: The Caledonides of central-north Scandinavia-a tectonostratigraphic overview. In Gee, D.G. \& Sturt, B.A. (eds.): The Caledonide Orogen-Scandinavia and Related Areas, John Wiley \& Sons, Ltd., Chichester, 135-162.

Sterner, S.M., Hall, D.L. \& Bodnar, R.J. 1988: Synthetic fluid inclusions. V. Solubility relations in the system $\mathrm{NaCl}-\mathrm{KCl}-\mathrm{H} 2 \mathrm{O}$ under vaporsaturated conditions. Geochimica et Cosmochimica Acta 52, 9891005. doi: http://dx.doi.org/10.1016/0016-7037(88)90254-2.

Svenningsen, O.M. 1994: Tectonic significance of the meta-evaporitic magnesite and scapolite deposits in the Seve Nappes, Sarek Mts., Swedish Caledonides. Tectonophysics 231, 33-44.

Thiery, R., Van den Kerkhof, A. \& Dubessey, J. 1994: VX properties of $\mathrm{CH} 4-\mathrm{CO} 2$ and $\mathrm{CO} 2-\mathrm{N} 2$. Modelling for fluid inclusions (T! 31 8C; P! 400 bar). European Journal of Mineralogy 6, 753-771.

Touret, J.L.R. \& Nijland, T.G. 2013: Prograde, Peak and Retrograde Metamorphic Fluids and Associated Metasomatism in Upper Amphibolite to Granulite Facies Transition Zones. In Harlov, D.E., Austrheim, H. (eds.): Metasomatism and the Chemical Transformation of Rock, Lecture Notes in Earth System Sciences, Springer, Berlin Heidelberg, 415-469. doi: 10.1007/978-3-642-28394-9_11.

Ulrich, T., Günther, D. \& Heinrich, C.A. 2001: The Evolution of a Porphyry $\mathrm{Cu}-\mathrm{Au}$ Deposit, Based on LA-ICP-MS Analysis of Fluid Inclusions: Bajo de la Alumbrera, Argentina. Economic Geology 96, 1743-1774. doi: 10.2113/gsecongeo.96.8.1743.

Vry, J., Powell, R., Golden, K.M. \& Petersen, K. 2010: The role of exhumation in metamorphic dehydration and fluid production. Nature Geosci 3, 31-35. doi: http://www.nature.com/ngeo/journal/v3/n1/ suppinfo/ngeo699_S1.html

Wells, M.K. \& Bradshaw, R. 1970: Multiple folding in the Sørfinnset area of northern Norway. Norges geologiske undersøkelse 242, 1-89.

Wesolowski, D. 1984: Geochemistry of tungsten in scheelite deposits: the skarn ores at King Island, Tasmania. PhD thesis, Pennsylvania State University, $465 \mathrm{pp}$.

Wood, S.A. \& Samson, I.M. 2000: The Hydrothermal Geochemistry of Tungsten in Granitoid Environments: I. Relative Solubilities of Ferberite and Scheelite as a Function of T, $\mathrm{P}, \mathrm{pH}$, and $\mathrm{mNaCl}$. Economic Geology 95, 143-182.

Yardley, B.D. 2013: The Chemical Composition of Metasomatic Fluids in the Crust. In Harlov, D.E., Austrheim, H. (eds.): Metasomatism and the Chemical Transformation of Rock, Lecture Notes in Earth System Sciences, Springer, Berlin Heidelberg, pp. 17-51. doi: 
10.1007/978-3-642-28394-9_2.

Yoshinobu, A.S., Barnes, C.G., Nordgulen, Ø., Prestvik, T., Fanning, M. \& Pedersen, R.B. 2002: Ordovician magmatism, deformation, and exhumation in the Caledonides of central Norway: An orphan of the Taconic orogeny? Geology 30, 883-886. doi: 10.1130/0091-7613(2002)030<0883:omdaei>2.0.co;2.

Zwaan, K., Fareth, E. \& Grogan, P. 1998: Geologisk kart over Norge, berggrunnskart Tromsø, Scale 1:250,000, Norges geologiske undersøkelse. 